\title{
LEVEL II SCOUR ANALYSIS FOR BRIDGE 68 (NFIETH00960068) on TOWN HIGHWAY 96, crossing the DOG RIVER, NORTHFIELD, VERMONT
}

U.S. Geological Survey Open-File Report 97-590

Prepared in cooperation with

VERMONT AGENCY OF TRANSPORTATION and

FEDERAL HIGHWAY ADMINISTRATION 


\section{LEVEL II SCOUR ANALYSIS FOR BRIDGE 68 (NFIETH00960068) on TOWN HIGHWAY 96, crossing the DOG RIVER, NORTHFIELD, VERMONT \\ By RONDA L. BURNS}

U.S. Geological Survey Open-File Report 97-590

Prepared in cooperation with

VERMONT AGENCY OF TRANSPORTATION and

FEDERAL HIGHWAY ADMINISTRATION 


\title{
U.S. DEPARTMENT OF THE INTERIOR BRUCE BABBITT, Secretary
}

\author{
U.S. GEOLOGICAL SURVEY \\ Gordon P. Eaton, Director
}

For additional information write to:

District Chief

U.S. Geological Survey 361 Commerce Way

Pembroke, NH 03275-3718
Copies of this report may be purchased from:

U.S. Geological Survey

Branch of Information Services

Open-File Reports Unit

Box 25286

Denver, CO 80225-0286 


\section{CONTENTS}

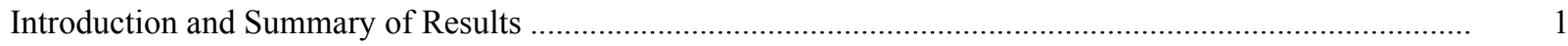

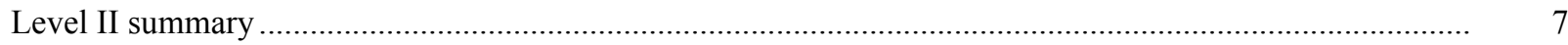

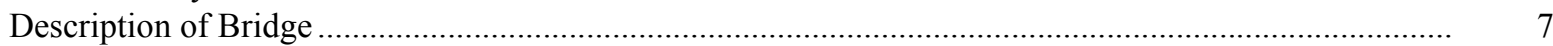

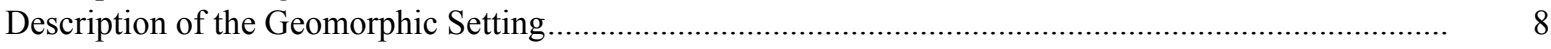

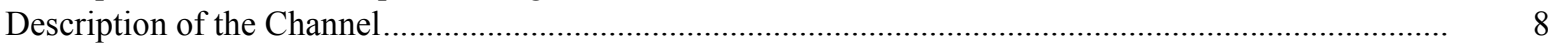

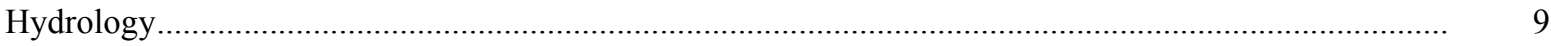

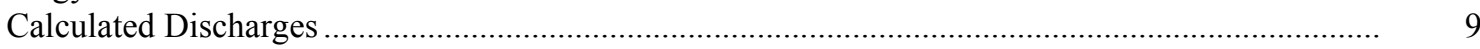

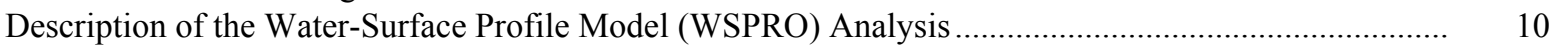

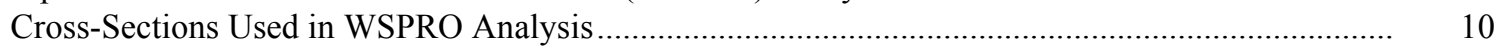

Data and Assumptions Used in WSPRO Model ...................................................................... 11

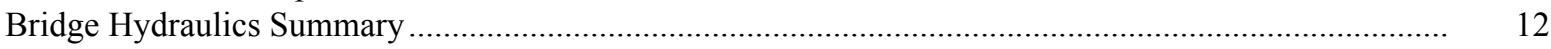

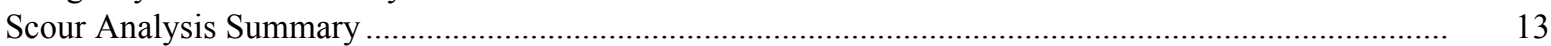

Special Conditions or Assumptions Made in Scour Analysis ...................................................... 13

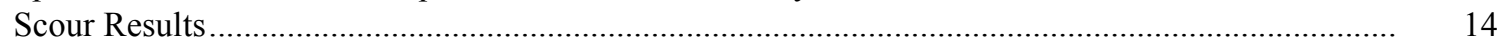

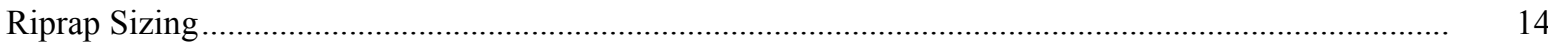

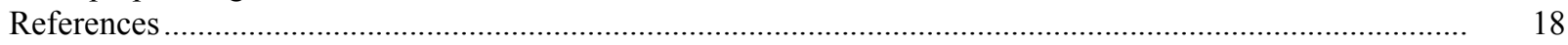

Appendixes:

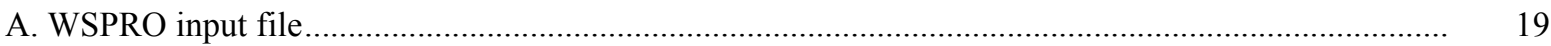

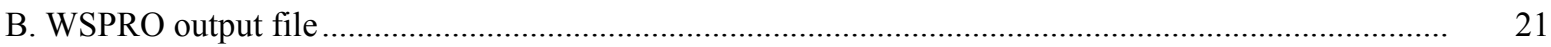

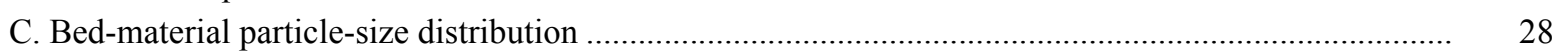

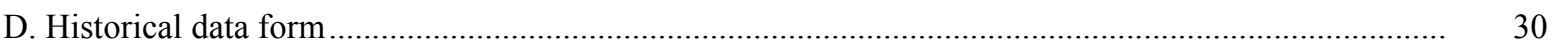

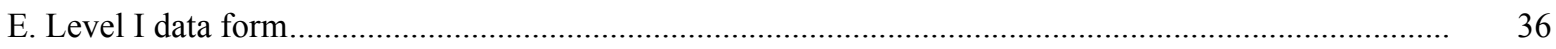

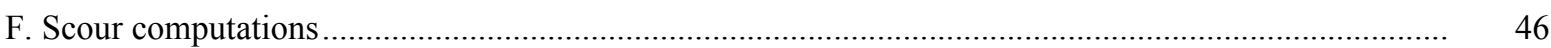

\section{FIGURES}

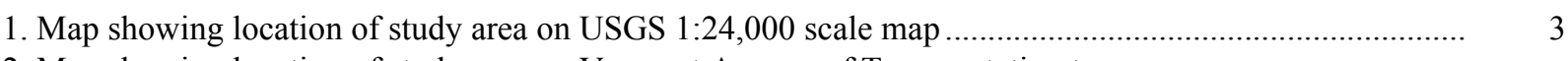

2. Map showing location of study area on Vermont Agency of Transportation town
highway map

3. Structure NFIETH00960068 viewed from upstream (July 25, 1996) .....................................................

4. Downstream channel viewed from structure NFIETH00960068 (July 25, 1996)................................ 5

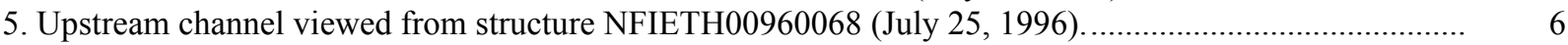

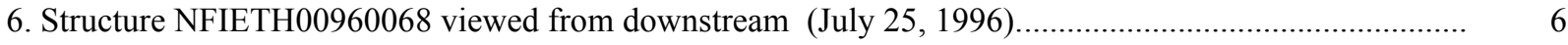

7. Water-surface profiles for the 100- and 500-year discharges at structure

NFIETH00960068 on Town Highway 96, crossing the Dog River,

Northfield, Vermont.

8. Scour elevations for the 100- and 500-year discharges at structure

NFIETH00960068 on Town Highway 96, crossing the Dog River,

Northfield, Vermont.

\section{TABLES}

1. Remaining footing/pile depth at abutments for the 100-year discharge at structure

NFIETH00960068 on Town Highway 96, crossing the Dog River,

Northfield, Vermont.

2. Remaining footing/pile depth at abutments for the 500-year discharge at structure

NFIETH00960068 on Town Highway 96, crossing the Dog River,

Northfield, Vermont.

3
5
5
6
列 


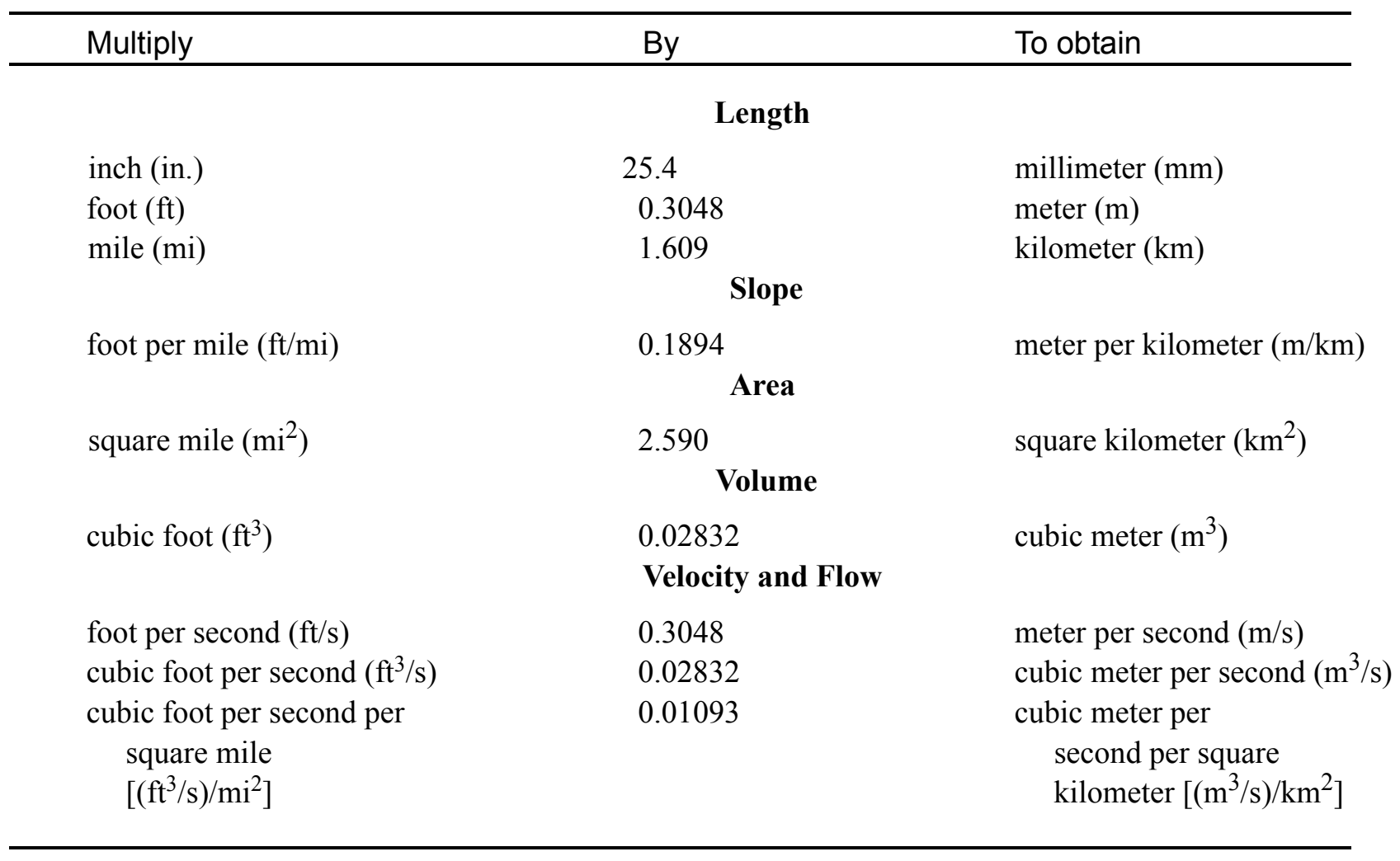

\section{OTHER ABBREVIATIONS}

$\begin{array}{lrlr}\mathrm{BF} & \text { bank full } & \text { LWW } & \text { left wingwall } \\ \mathrm{cfs} & \text { cubic feet per second } & \text { MC } & \text { main channel } \\ \mathrm{D}_{50} & \text { median diameter of bed material } & \text { RAB } & \text { right abutment } \\ \mathrm{DS} & \text { downstream } & \text { RABUT } & \text { face of right abutment } \\ \mathrm{elev} & \text { elevation } & \text { RB } & \text { right bank } \\ \mathrm{f} / \mathrm{p} & \text { flood plain } & \text { ROB } & \text { right overbank } \\ \mathrm{ft}^{2} & \text { square feet } & \text { RWW } & \text { right wingwall } \\ \mathrm{ft} / \mathrm{ft} & \text { feet per foot } & \text { TH } & \text { town highway } \\ \mathrm{JCT} & \text { junction } & \text { UB } & \text { under bridge } \\ \mathrm{LAB} & \text { left abutment } & \text { US } & \text { upstream } \\ \mathrm{LABUT} & \text { face of left abutment } & \text { USGS } & \text { United States Geological Survey } \\ \mathrm{LB} & \text { left bank } & \text { VTAOT Vermont Agency of Transportation } \\ \mathrm{LOB} & \text { left overbank } & \text { WSPRO } & \text { water-surface profile model }\end{array}$

In this report, the words "right" and "left" refer to directions that would be reported by an observer facing downstream. Sea level: In this report, "sea level" refers to the National Geodetic Vertical Datum of 1929-- a geodetic datum derived from a general adjustment of the first-order level nets of the United States and Canada, formerly called Sea Level Datum of 1929.

In the appendices, the above abbreviations may be combined. For example, USLB would represent upstream left bank. 


\title{
LEVEL II SCOUR ANALYSIS FOR BRIDGE 68 (NFIETH00960068) ON TOWN HIGHWAY 96, CROSSING THE DOG RIVER, NORTHFIELD, VERMONT
}

\author{
By Ronda L. Burns
}

\section{INTRODUCTION AND SUMMARY OF RESULTS}

This report provides the results of a detailed Level II analysis of scour potential at structure NFIETH00960068 on Town Highway 96 crossing the Dog River, Northfield, Vermont (figures 1-8). A Level II study is a basic engineering analysis of the site, including a quantitative analysis of stream stability and scour (U.S. Department of Transportation, 1993). Results of a Level I scour investigation also are included in Appendix E of this report. A Level I investigation provides a qualitative geomorphic characterization of the study site. Information on the bridge, gleaned from Vermont Agency of Transportation (VTAOT) files, was compiled prior to conducting Level I and Level II analyses and is found in Appendix D.

The site is in the Green Mountain section of the New England physiographic province in central Vermont. The $30.7-\mathrm{mi}^{2}$ drainage area is in a predominantly rural and forested basin. In the vicinity of the study site, the surface cover on the left bank upstream and downstream is pasture while the immediate banks have dense woody vegetation. The right bank upstream is forested and the downstream right bank is pasture. Vermont state route $12 \mathrm{~A}$ runs parallel to the river on the right bank.

In the study area, the Dog River has an incised, straight channel with a slope of approximately $0.004 \mathrm{ft} / \mathrm{ft}$, an average channel top width of $70 \mathrm{ft}$ and an average bank height of $7 \mathrm{ft}$. The channel bed material ranges from sand to cobble with a median grain size $\left(\mathrm{D}_{50}\right)$ of $47.9 \mathrm{~mm}(0.157 \mathrm{ft})$. The geomorphic assessment at the time of the Level I and Level II site visit on July 25,1996 , indicated that the reach was stable.

The Town Highway 96 crossing of the Dog River is a 45-ft-long, one-lane bridge consisting of one 43-foot steel-beam span with a timber deck (Vermont Agency of Transportation, written communication, October 13, 1995). The opening length of the structure parallel to the bridge face is $41.5 \mathrm{ft}$.The bridge is supported by vertical, concrete abutments with wingwalls. The channel is not skewed to the opening and the opening-skew-to-roadway is zero degrees. 
Channel scour $0.5 \mathrm{ft}$ deeper than the mean thalweg depth, was observed under the bridge during the Level I assessment. The scour protection measures at the site included type-1 stone fill (less than 12 inches diameter) along the left bank upstream and type-2 stone fill (less than 36 inches diameter) along the upstream and downstream right banks that extends partially in front of the right wingwalls. Additional details describing conditions at the site are included in the Level II Summary and Appendices D and E.

Scour depths and recommended rock rip-rap sizes were computed using the general guidelines described in Hydraulic Engineering Circular 18 (Richardson and others, 1995). Total scour at a highway crossing is comprised of three components: 1) long-term streambed degradation; 2) contraction scour (due to accelerated flow caused by a reduction in flow area at a bridge) and; 3 ) local scour (caused by accelerated flow around piers and abutments). Total scour is the sum of the three components. Equations are available to compute depths for contraction and local scour and a summary of the results of these computations follows.

Contraction scour for all modelled flows ranged from 0.8 to $1.2 \mathrm{ft}$. The worst-case contraction scour occurred at the 100-year and 500-year discharges. Abutment scour ranged from 8.5 to $12.2 \mathrm{ft}$. The worst-case abutment scour occurred at the incipient roadwayovertopping discharge for the right abutment. Additional information on scour depths and depths to armoring are included in the section titled "Scour Results". Scoured-streambed elevations, based on the calculated scour depths, are presented in tables 1 and 2. A crosssection of the scour computed at the bridge is presented in figure 8. Scour depths were calculated assuming an infinite depth of erosive material and a homogeneous particle-size distribution.

It is generally accepted that the Froehlich equation (abutment scour) gives "excessively conservative estimates of scour depths" (Richardson and others, 1995, p. 47). Usually, computed scour depths are evaluated in combination with other information including (but not limited to) historical performance during flood events, the geomorphic stability assessment, existing scour protection measures, and the results of the hydraulic analyses. Therefore, scour depths adopted by VTAOT may differ from the computed values documented herein. 


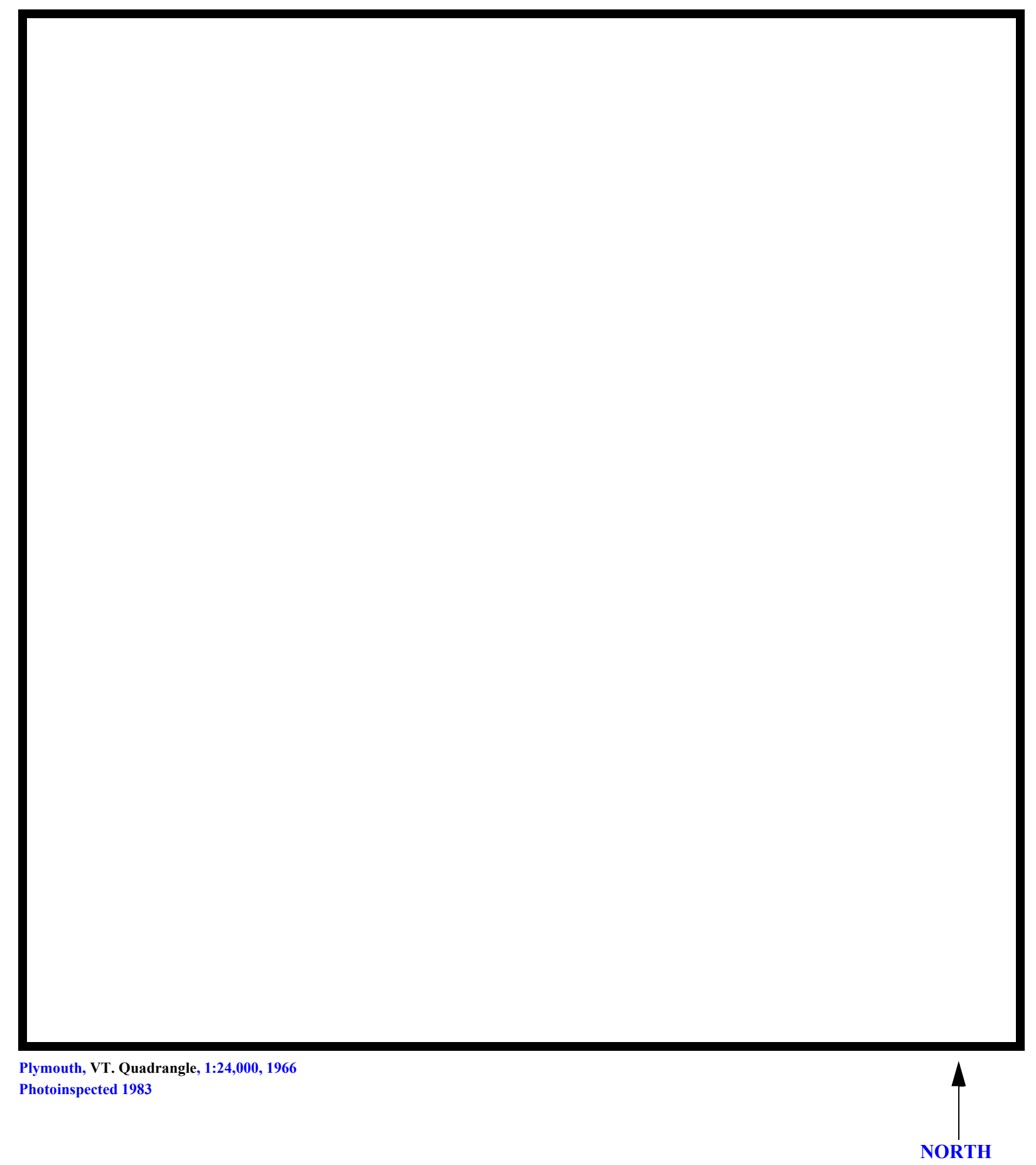

Figure 1. Location of study area on USGS 1:24,000 scale map. 
Figure 2. Location of study area on Vermont Agency of Transportation town highway map. 

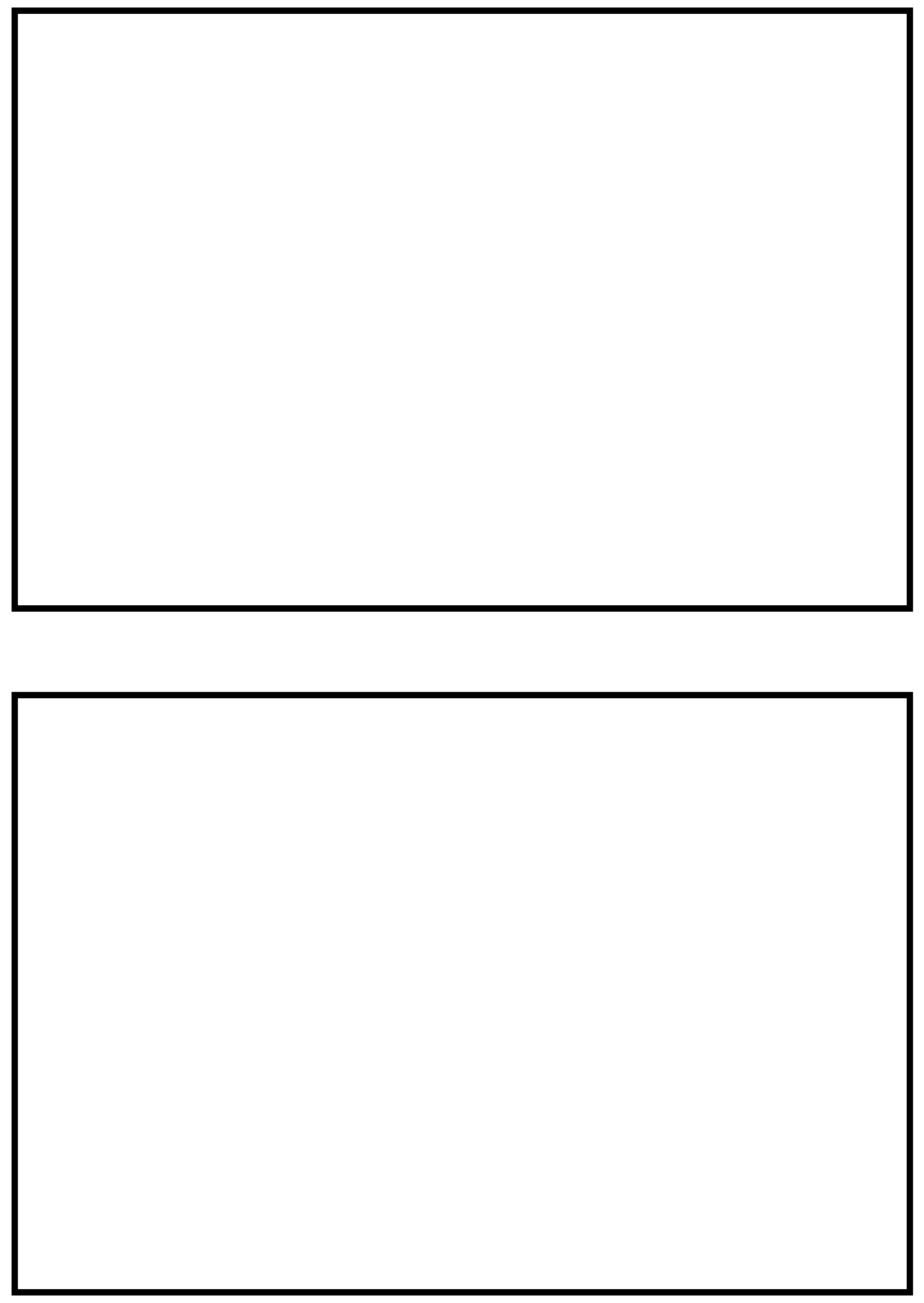

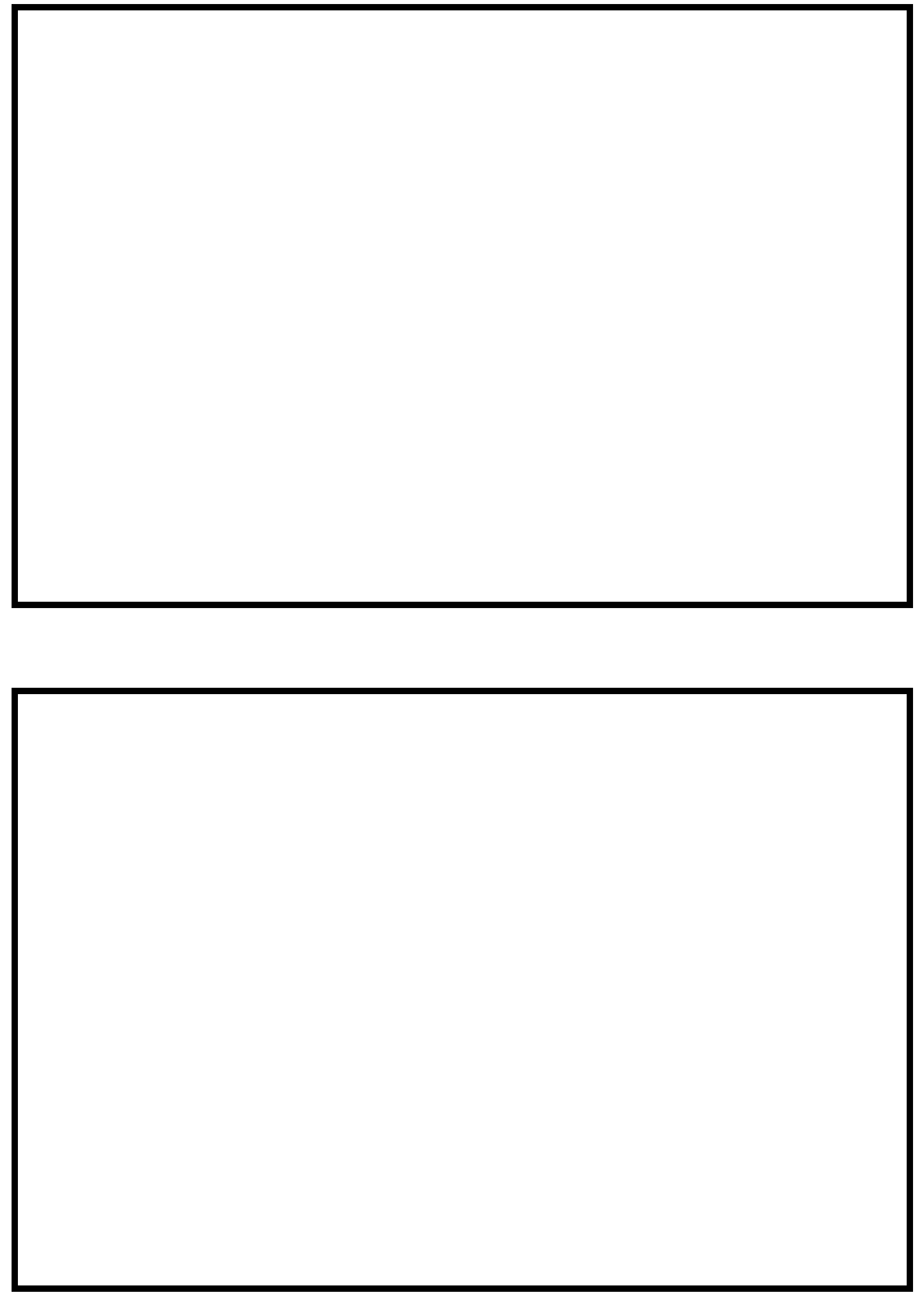


\section{LEVEL II SUMMARY}

\begin{tabular}{llllll} 
Structure Number & NFIETH00960068 & Stream & \multicolumn{2}{c}{ Dog River } & \\
& Noushington & Road & TH96 & District & 6
\end{tabular}

\section{Description of Bridge}

Bridge length $\frac{45}{4} \boldsymbol{f t}$ Bridge width $\frac{16.9}{f t} \quad$ Max span length $\stackrel{43}{f t}$ Alignment of bridge to road (on curve or straight)

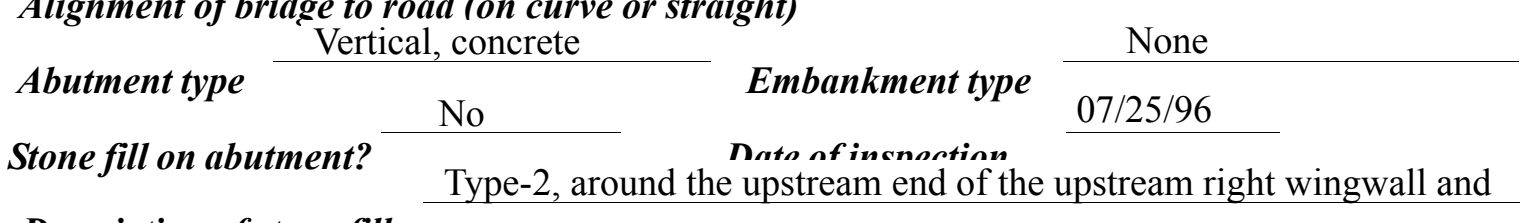
the downstream end of the downstream right wingwall.

Abutments and wingwalls are concrete. The footing for the right abutment and its wingwalls is exposed.

No $\quad \underline{0}$

Is bridge skewed to flood flow according to No ' survey? Angle

Debris accumulation on bridge at time of Level I or Level II site visit:

\begin{tabular}{|c|c|c|c|}
\hline & $\begin{array}{c}\text { Date of insnortion } \\
07 / 25 / 96 \\
\end{array}$ & $\begin{array}{l}\text { Percent of abmunal } \\
\text { blocked hortzontatly }\end{array}$ & $\begin{array}{l}\text { Percent of } 0 \\
\text { blocked verticatty }\end{array}$ \\
\hline & $07 / 25 / 96$ & 0 & 0 \\
\hline & Low. & & \\
\hline
\end{tabular}

Potential for debris

None 07/25/96.

Dosrriho any, foaturos noar ar at tho hridoo that mav, affort flow, (includo ahsorvation dato) 


\section{Description of the Geomorphic Setting}

General topography The channel is located within a moderate relief valley with a 400 foot-wide, flat to slightly irregular flood plain on the left and a steep valley wall on the right.

Geomorphic conditions at bridge site: downstream (DS), upstream (US)

Date of inspection $\quad 07 / 25 / 96$

DS left: $\quad$ Steep channel bank to a flood plain

DS right: $\quad$ Steep valley wall

US left: $\quad$ Steep channel bank to a flood plain

US right: $\quad$ Steep valley wall

\section{Description of the Channel}

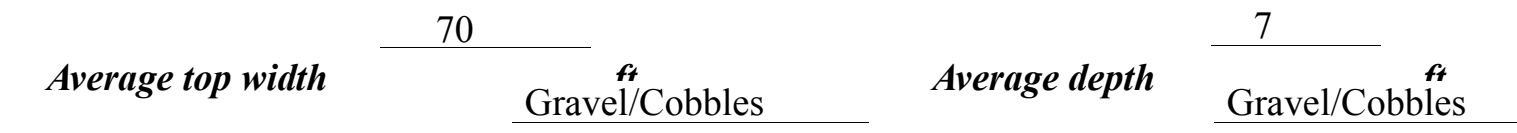

Predominant bed material

Bank material Straight with semi-

alluvial channel boundaries and a flood plain on the left.

$07 / 25 / 96$

Vegetative co ${ }^{1}$ Trees and brush with grass on the overbank

DS left: $\quad$ Grass with trees on the overbank

DS right: $\quad$ Trees and brush with grass on the overbank

US left: $\quad$ Brush with trees on the overbank

US right: $\quad$ Yes

Do banks appear stable? -

y mus, ме

date of observatton.

None $07 / 25 / 96$.

Describe any obstructions in channel and date of observation. 


\title{
Hydrology
}

Drainage area $\stackrel{30.7}{\boldsymbol{m i}^{2}}$

Percentage of drainage area in physiographic provinces: (approximate)

Physiographic province/section

New England/Green Mountain
Percent of drainage area 100

\begin{abstract}
Is drainage area considered rural or urban? Rural _ Describe any significant urbanization:
\end{abstract}

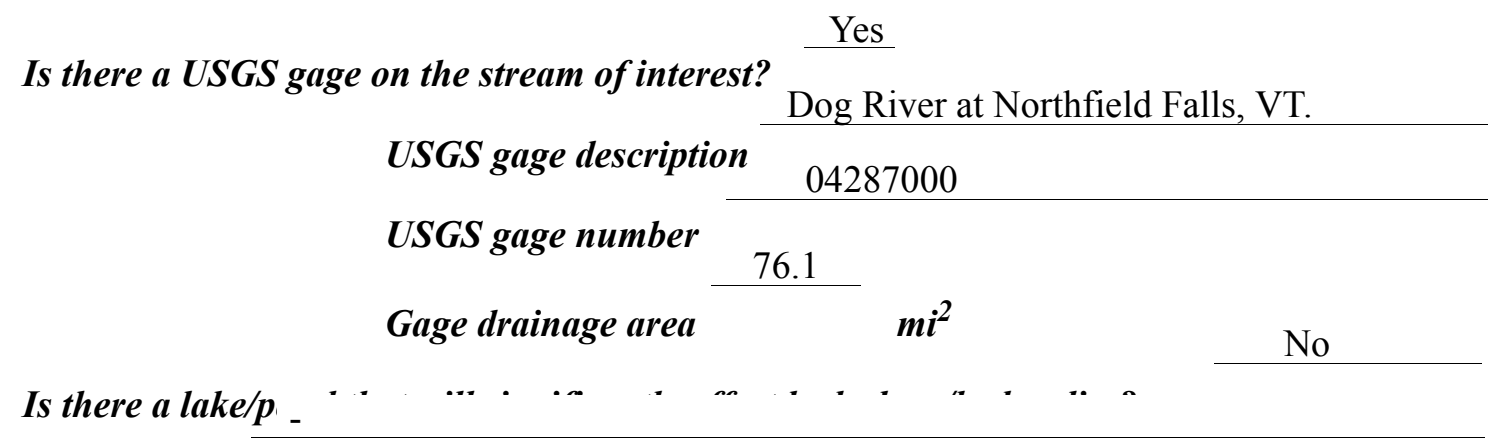

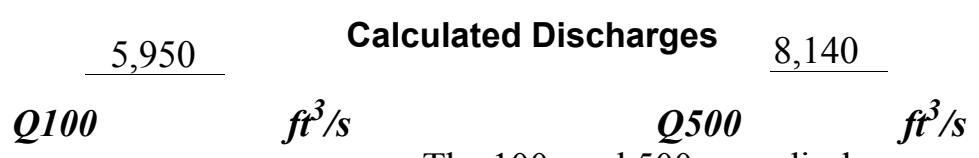

The 100- and 500-year discharges are based on a

drainage area relationship.[(30.7/76.1) exp 0.75] with the flood frequency determinations at the USGS gage at Northfield Falls in Northfield. The flood frequency values for the gage were determined using a log-Pearson type III analysis on 59 years of stream flow records from 1935 to 1993. 


\section{Description of the Water-Surface Profile Model (WSPRO) Analysis}

Datum for WSPRO analysis (USGS survey, sea level, VTAOT plans)

USGS survey

Datum tie between USGS survey and VTAOT plans

None

Description of reference marks used to determine USGS datum. $\quad$ RM1 is a chiseled X on top of the upstream end of the right abutment (elev. $499.39 \mathrm{ft}$, arbitrary survey datum). RM2 is a nail $5 \mathrm{ft}$ above the ground surface in an utility pole located $50 \mathrm{ft}$ left of the left abutment on the downstream side of TH 96 (elev. $503.60 \mathrm{ft}$, arbitrary survey datum).

\section{Cross-Sections Used in WSPRO Analysis}

\begin{tabular}{cccl}
\hline${ }^{1}$ Cross-section & $\begin{array}{c}\text { Section } \\
\text { Reference } \\
\text { Distance } \\
\text { (SRD) in feet }\end{array}$ & $\begin{array}{c}{ }^{2} \text { Cross-section } \\
\text { development }\end{array}$ & \multicolumn{1}{c}{ Comments } \\
\hline EXITX & -43 & 1 & Exit section \\
FULLV & 0 & 2 & $\begin{array}{l}\text { Downstream Full-valley } \\
\text { section (Templated from } \\
\text { EXITX) }\end{array}$ \\
BRIDG & 0 & 1 & Bridge section \\
RDWAY & 11 & 1 & Road Grade section \\
APPRO & 61 & 1 & Approach section \\
\hline
\end{tabular}

${ }^{1}$ For location of cross-sections see plan-view sketch included with Level I field form, Appendix E. For more detail on how cross-sections were developed see WSPRO input file. 


\section{Data and Assumptions Used in WSPRO Model}

Hydraulic analyses of the reach were done by use of the Federal Highway Administration's WSPRO step-backwater computer program (Shearman and others, 1986, and Shearman, 1990). The analyses reported herein reflect conditions existing at the site at the time of the study. Furthermore, in the development of the model it was necessary to assume no accumulation of debris or ice at the site. Results of the hydraulic model are presented in the Bridge Hydraulic Summary, Appendix B, and figure 7.

Channel roughness factors (Manning's " $n$ ") used in the hydraulic model were estimated using field inspections at each cross section following the general guidelines described by Arcement and Schneider (1989). Final adjustments to the values were made during the modelling of the reach. Channel " $n$ " values for the reach ranged from 0.040 to 0.055 , and overbank " $\mathrm{n}$ " values ranged from 0.032 to 0.045 .

Normal depth at the exit section (EXITX) was assumed as the starting water surface. This depth was computed by use of the slope-conveyance method outlined in the user's manual for WSPRO (Shearman, 1990). The slope used was $0.0041 \mathrm{ft} / \mathrm{ft}$ which was estimated from the streambed slope downstream of the bridge on the river profile in the Flood Insurance Study for Northfield, VT (U. S. Department of Housing and Urban Development, November 1977).

The surveyed approach section (APPRO) was one bridge length upstream of the upstream face as recommended by Shearman and others (1986). This location also provides a consistent method for determining scour variables. 


\section{Bridge Hydraulics Summary}

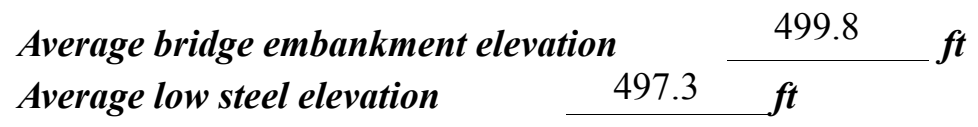

$$
\text { 100-year discharge } \quad 5,950 \quad \mathrm{ft}^{3} / \mathrm{s}
$$

Water-surface elevation in bridge opening $\quad 497.4 \quad f t$

Road overtopping? ___ Yes Discharge over road __ 2,304 $\mathrm{ft}^{3} / \mathrm{s}$

\begin{tabular}{lc} 
Area of flow in bridge opening & $389 \quad \boldsymbol{f t}^{2}$ \\
\cline { 2 - 2 } Average velocity in bridge opening & 9.4
\end{tabular}

$\begin{array}{llll}\text { Maximum WSPRO tube velocity at bridge } & 10.9 \mathrm{ft} / \mathrm{s}\end{array}$

Water-surface elevation at Approach section with bridge $\quad 500.0$

Water-surface elevation at Approach section without bridge $\quad$\begin{tabular}{r}
497.9 \\
\cline { 2 - 2 }
\end{tabular}

Amount of backwater caused by bridge $\quad 2.1$ it

500-year discharge $\quad 8,140 \quad \mathrm{ft}^{3} / \mathrm{s}$

Water-surface elevation in bridge opening $497.4 \mathrm{ft}$

Road overtopping? ___ Yes Discharge over road __ 4,463 $\mathrm{ft}^{3} / \mathrm{s}$

Area of flow in bridge opening $\quad 389 \quad \mathrm{ft}^{2}$

Average velocity in bridge opening $\quad 9.5 \mathrm{ft} / \mathrm{s}$

Maximum WSPRO tube velocity at bridge $11.0 \_$'s

Water-surface elevation at Approach section with bridge $\quad 500.7$

Water-surface elevation at Approach section without bridge $\quad 498.6$

Amount of backwater caused by bridge $\quad 2.1, t$

Incipient overtopping discharge $\quad 3,390 \mathrm{ft}^{3} / \mathrm{s}$

Water-surface elevation in bridge opening $495.8 \quad t$

Area of flow in bridge opening $\quad 325 \quad \mathrm{ft}^{2}$

Average velocity in bridge opening $\quad 10.4 \quad \mathrm{ft} / \mathrm{s}$

Maximum WSPRO tube velocity at bridge $\quad 12.6 \mathrm{ft} / \mathrm{s}$

Water-surface elevation at Approach section with bridge

Water-surface elevation at Approach section without bridge

497.5

Amount of backwater caused by bridge $\quad 0.8$ it

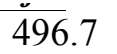




\section{Scour Analysis Summary}

\section{Special Conditions or Assumptions Made in Scour Analysis}

Scour depths were computed using the general guidelines described in Hydraulic Engineering Circular 18 (Richardson and others, 1995). Scour depths were calculated assuming an infinite depth of erosive material and a homogeneous particle-size distribution. The results of the scour analysis are presented in tables 1 and 2 and a graph of the scour depths is presented in figure 8 .

Contraction scour for the incipient road-overtopping discharge was computed by use of the Laursen clear-water contraction scour equation (Richardson and others, 1995, p. 32, equation 20). At this site, the 100-year and 500-year discharges resulted in submerged orifice flow. Contraction scour at bridges with orifice flow is best estimated by use of the Chang pressure-flow scour equation (oral communication, J. Sterling Jones, October 4, 1996). Thus, contraction scour for these discharges was computed by use of the Chang equation (Richardson and others, 1995, p. 145-146). Estimates of contraction scour for the 100 -year and 500-year discharges were also computed by use of the Laursen clear-water contraction scour equation and the Umbrell pressure-flow equation (Richardson and others, 1995, p. 144) and are presented in Appendix F. The streambed armoring depths computed suggest that armoring will not limit the depth of contraction scour.

Abutment scour for the right abutment was computed by use of the Froehlich equation (Richardson and others, 1995, p. 48, equation 28). Variables for the Froehlich equation include the Froude number of the flow approaching the embankments, the length of the embankment blocking flow, and the depth of flow approaching the embankment less any roadway overtopping.

Scour at the left abutment was computed by use of the HIRE equation (Richardson and others, 1995, p. 49, equation 29) because the HIRE equation is recommended when the length to depth ratio of the embankment blocking flow exceeds 25 . The variables used by the HIRE abutment-scour equation are defined the same as those defined for the Froehlich abutment-scour equation. 


\section{Scour Results}

\section{0-yr discharge 500-yr discharge}

Contraction scour:

(Scour depths in feet)

Main channel

Live-bed scour

Clear-water scour

Depth to armoring

Left overbank

Right overbank

Local scour:

Abutment scour

Left abutment

8.5

9.4

9.3

10.9

11.5

$12.2-$

Right abutment

Pier scour

Pier 1

Pier 2

Pier 3

\section{Abutments:}

Left abutment

Right abutment

Piers:

Pier 1

Pier 2

overtopping discharge 


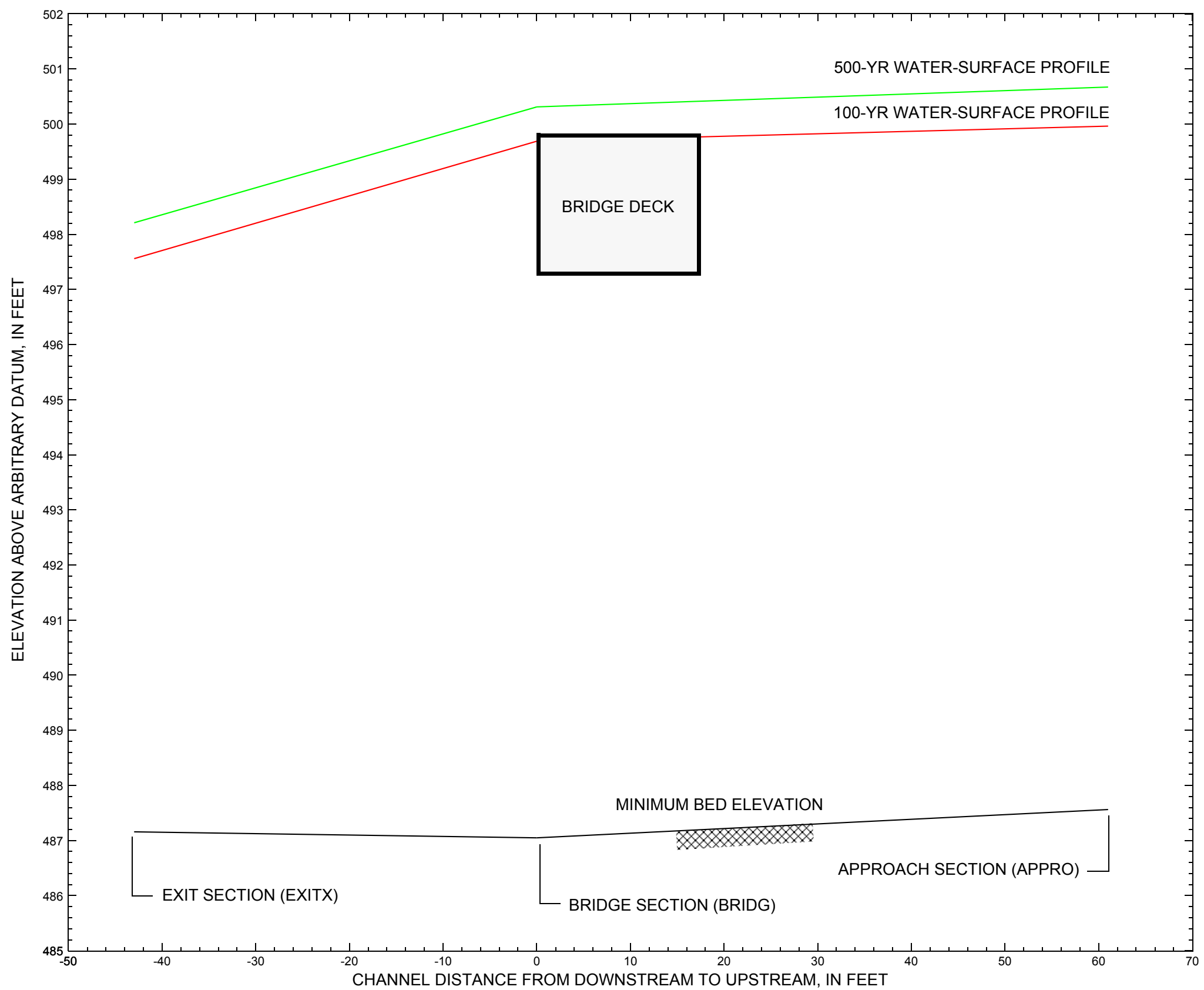

Figure 7. Water-surface profiles for the 100- and 500-yr discharges at structure NFIETH00960068 on Town Highway 96, crossing the Dog River, Northfield, Vermont. 


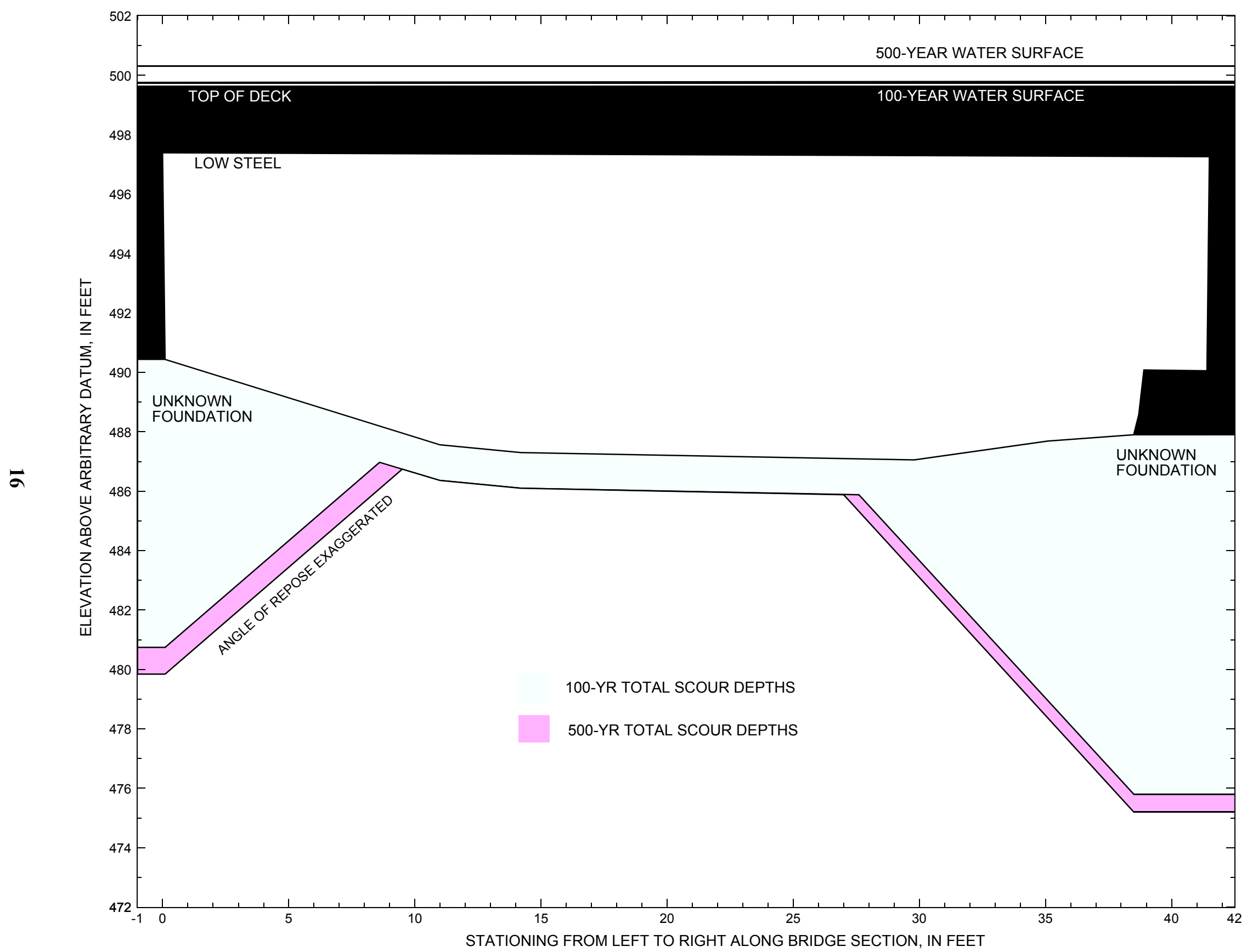

Figure 8. Scour elevations for the 100-yr and 500-yr discharges at structure NFIETH00960068 on Town Highway 96, crossing the Dog River, Northfield, Vermont. 
Table 1. Remaining footing/pile depth at abutments for the 100-year discharge at structure NFIETH00960068 on Town Highway 96, crossing the Dog River, Northfield, Vermont.

[VTAOT, Vermont Agency of Transportation; --, no data]

\begin{tabular}{|c|c|c|c|c|c|c|c|c|c|c|c|}
\hline Description & Station $^{1}$ & $\begin{array}{l}\text { VTAOT } \\
\text { minimum } \\
\text { low-chord } \\
\text { elevation } \\
\text { (feet) }\end{array}$ & $\begin{array}{l}\text { Surveyed } \\
\text { minimum } \\
\text { low-chord } \\
\text { elevation } \\
\text { (feet) }\end{array}$ & $\begin{array}{c}\text { Bottom of } \\
\text { footing/pile } \\
\text { elevation }{ }^{2} \\
\text { (feet) }\end{array}$ & $\begin{array}{l}\text { Channel } \\
\text { elevation at } \\
\text { abutment/ } \\
\text { pier }^{2} \\
\text { (feet) }\end{array}$ & $\begin{array}{l}\text { Contraction } \\
\text { scour depth } \\
\text { (feet) }\end{array}$ & $\begin{array}{l}\text { Abutment } \\
\text { scour } \\
\text { depth } \\
\text { (feet) }\end{array}$ & $\begin{array}{l}\text { Pier } \\
\text { scour } \\
\text { depth } \\
\text { (feet) }\end{array}$ & $\begin{array}{l}\text { Depth of } \\
\text { total scour } \\
\text { (feet) }\end{array}$ & $\begin{array}{c}\text { Elevation of } \\
\text { scour }^{2} \\
\text { (feet) }\end{array}$ & $\begin{array}{c}\text { Remaining } \\
\text { footing/pile } \\
\text { depth } \\
\text { (feet) }\end{array}$ \\
\hline \multicolumn{12}{|c|}{100 -yr. discharge is 5,950 cubic-feet per second } \\
\hline Left abutment & 0.0 & -- & 497.4 & -- & 490.4 & 1.2 & 8.5 & -- & 9.7 & 480.7 & -- \\
\hline Right abutment & 41.5 & -- & 497.3 & -- & 487.9 & 1.2 & 10.9 & -- & 12.1 & 475.8 & -- \\
\hline
\end{tabular}

1.Measured along the face of the most constricting side of the bridge.

2.Arbitrary datum for this study.

Table 2. Remaining footing/pile depth at abutments for the 500-year discharge at structure NFIETH00960068 on Town Highway 96, crossing the Dog River, Northfield, Vermont.

[VTAOT, Vermont Agency of Transportation; --, no data]

\begin{tabular}{|c|c|c|c|c|c|c|c|c|c|c|c|}
\hline Description & Station $^{1}$ & $\begin{array}{l}\text { VTAOT } \\
\text { minimum } \\
\text { low-chord } \\
\text { elevation } \\
\text { (feet) }\end{array}$ & $\begin{array}{c}\text { Surveyed } \\
\text { minimum } \\
\text { low-chord } \\
\text { elevation } \\
\text { (feet) }\end{array}$ & $\begin{array}{c}\text { Bottom of } \\
\text { footing/pile } \\
\text { elevation } \\
\text { (feet) }\end{array}$ & $\begin{array}{c}\text { Channel } \\
\text { elevation at } \\
\text { abutment/ } \\
\text { pier }^{2} \\
\text { (feet) }\end{array}$ & $\begin{array}{l}\text { Contraction } \\
\text { scour depth } \\
\text { (feet) }\end{array}$ & $\begin{array}{c}\text { Abutment } \\
\text { scour } \\
\text { depth } \\
\text { (feet) }\end{array}$ & $\begin{array}{l}\text { Pier } \\
\text { scour } \\
\text { depth } \\
\text { (feet) }\end{array}$ & $\begin{array}{l}\text { Depth of } \\
\text { total scour } \\
\text { (feet) }\end{array}$ & $\begin{array}{c}\text { Elevation of } \\
\text { scour }^{2} \\
\text { (feet) }\end{array}$ & $\begin{array}{c}\text { Remaining } \\
\text { footing/pile } \\
\text { depth } \\
\text { (feet) }\end{array}$ \\
\hline \multicolumn{12}{|c|}{500 -yr. discharge is 8,140 cubic-feet per second } \\
\hline Left abutment & 0.0 & -- & 497.4 & -- & 490.4 & 1.2 & 9.4 & -- & 10.6 & 479.8 & -- \\
\hline Right abutment & 41.5 & -- & 497.3 & -- & 487.9 & 1.2 & 11.5 & -- & 12.7 & 475.2 & -- \\
\hline
\end{tabular}

1.Measured along the face of the most constricting side of the bridge.

2.Arbitrary datum for this study. 


\section{SELECTED REFERENCES}

Arcement, G.J., Jr., and Schneider, V.R., 1989, Guide for selecting Manning's roughness coefficients for natural channels and flood plains: U.S. Geological Survey Water-Supply Paper 2339, 38 p.

Barnes, H.H., Jr., 1967, Roughness characteristics of natural channels: U.S. Geological Survey Water-Supply Paper 1849, 213 p.

Benson, M. A., 1962, Factors Influencing the Occurrence of Floods in a Humid Region of Diverse Terrain: U.S. Geological Survey Water-Supply Paper $1580-\mathrm{B}, 64 \mathrm{p}$.

Brown, S.A. and Clyde, E.S., 1989, Design of riprap revetment: Federal Highway Administration Hydraulic Engineering Circular No. 11, Publication FHWA-IP-89-016, 156 p.

Federal Highway Administration, 1983, Runoff estimates for small watersheds and development of sound design: Federal Highway Administration Report FHWA-RD-77-158.

Federal Highway Administration, 1993, Stream Stability and Scour at Highway Bridges: Participant Workbook: Federal Highway Administration Report FHWA-HI-91-011.

Froehlich, D.C., 1989, Local scour at bridge abutments in Ports, M.A., ed., Hydraulic Engineering--Proceedings of the 1989 National Conference on Hydraulic Engineering: New York, American Society of Civil Engineers, p. 13-18.

Hayes, D.C.,1993, Site selection and collection of bridge-scour data in Delaware, Maryland, and Virginia: U.S. Geological Survey Water-Resources Investigation Report 93-4017, 23 p.

Interagency Advisory Committee on Water Data, 1982, Guidelines for determining flood flow frequency: U.S. Geological Survey, Bulletin 17B of the Hydrology Subcommittee, 190 p.

Johnson, C.G. and Tasker, G.D.,1974, Progress report on flood magnitude and frequency of Vermont streams: U.S. Geological Survey Open-File Report $74-130,37 \mathrm{p}$.

Lagasse, P.F., Schall, J.D., Johnson, F., Richardson, E.V., Chang, F., 1995, Stream Stability at Highway Structures: Federal Highway Administration Hydraulic Engineering Circular No. 20, Publication FHWA-IP-90-014, 144 p.

Laursen, E.M., 1960, Scour at bridge crossings: Journal of the Hydraulics Division, American Society of Civil Engineers, v. 86, no. HY2, p. $39-53$.

Potter, W. D., 1957a, Peak rates of runoff in the Adirondack, White Mountains, and Maine woods area, Bureau of Public Roads

Potter, W. D., 1957b, Peak rates of runoff in the New England Hill and Lowland area, Bureau of Public Roads

Richardson, E.V. and Davis, S.R., 1995, Evaluating scour at bridges: Federal Highway Administration Hydraulic Engineering Circular No. 18, Publication FHWA-IP-90-017, 204 p.

Richardson, E.V., Simons, D.B., and Julien, P.Y., 1990, Highways in the river environment: Federal Highway Administration Publication FHWA-HI90-016.

Ritter, D.F., 1984, Process Geomorphology: W.C. Brown Co., Debuque, Iowa, 603 p.

Shearman, J.O., 1990, User's manual for WSPRO--a computer model for water surface profile computations: Federal Highway Administration Publication FHWA-IP-89-027, 187 p.

Shearman, J.O., Kirby, W.H., Schneider, V.R., and Flippo, H.N., 1986, Bridge waterways analysis model; research report: Federal Highway Administration Publication FHWA-RD-86-108, 112 p.

Talbot, A.N., 1887, The determination of water-way for bridges and culverts.

U.S. Department of Housing and Urban Development, 1977, Flood Insurance Study, Town and Village of Northfield, Washington County, Vermont: Washington, D.C., November 1977.

U.S. Department of Transportation, 1993, Stream stability and scour at highway bridges, Participant Workbook: Federal Highway Administration Publication FHWA HI-91-011.

U.S. Geological Survey, 1980, Northfield, Vermont 7.5 Minute Series quadrangle map: U.S. Geological Survey Topographic Maps, Photoinspected 1983, Scale 1:24,000.

U.S. Geological Survey, 1980, Roxbury, Vermont 7.5 Minute Series quadrangle map: U.S. Geological Survey Topographic Maps, Photoinspected 1983, Scale 1:24,000. 


\section{APPENDIX A: \\ WSPRO INPUT FILE}




\section{APPENDIX B: \\ WSPRO OUTPUT FILE}




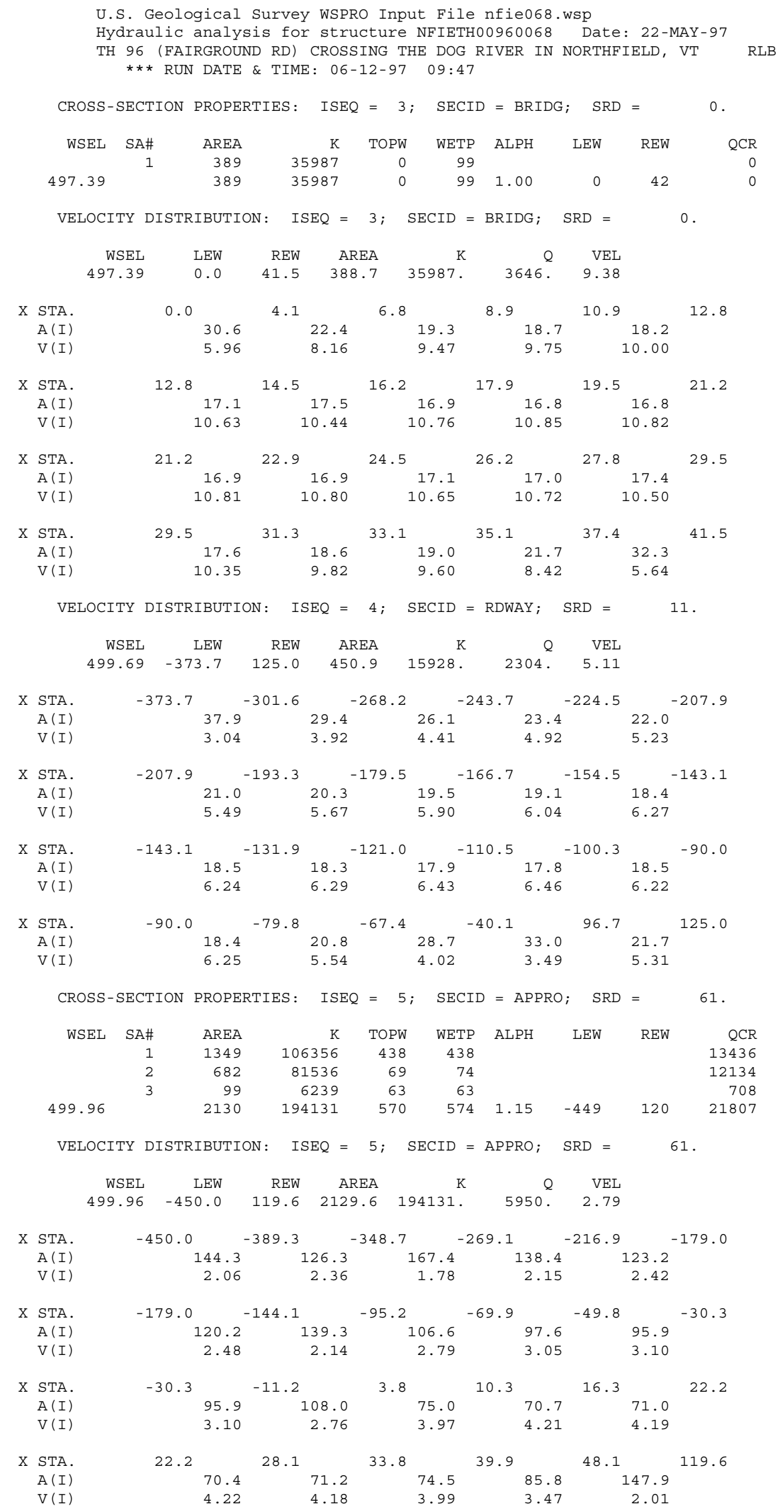


WSPRO OUTPUT FILE (continued)

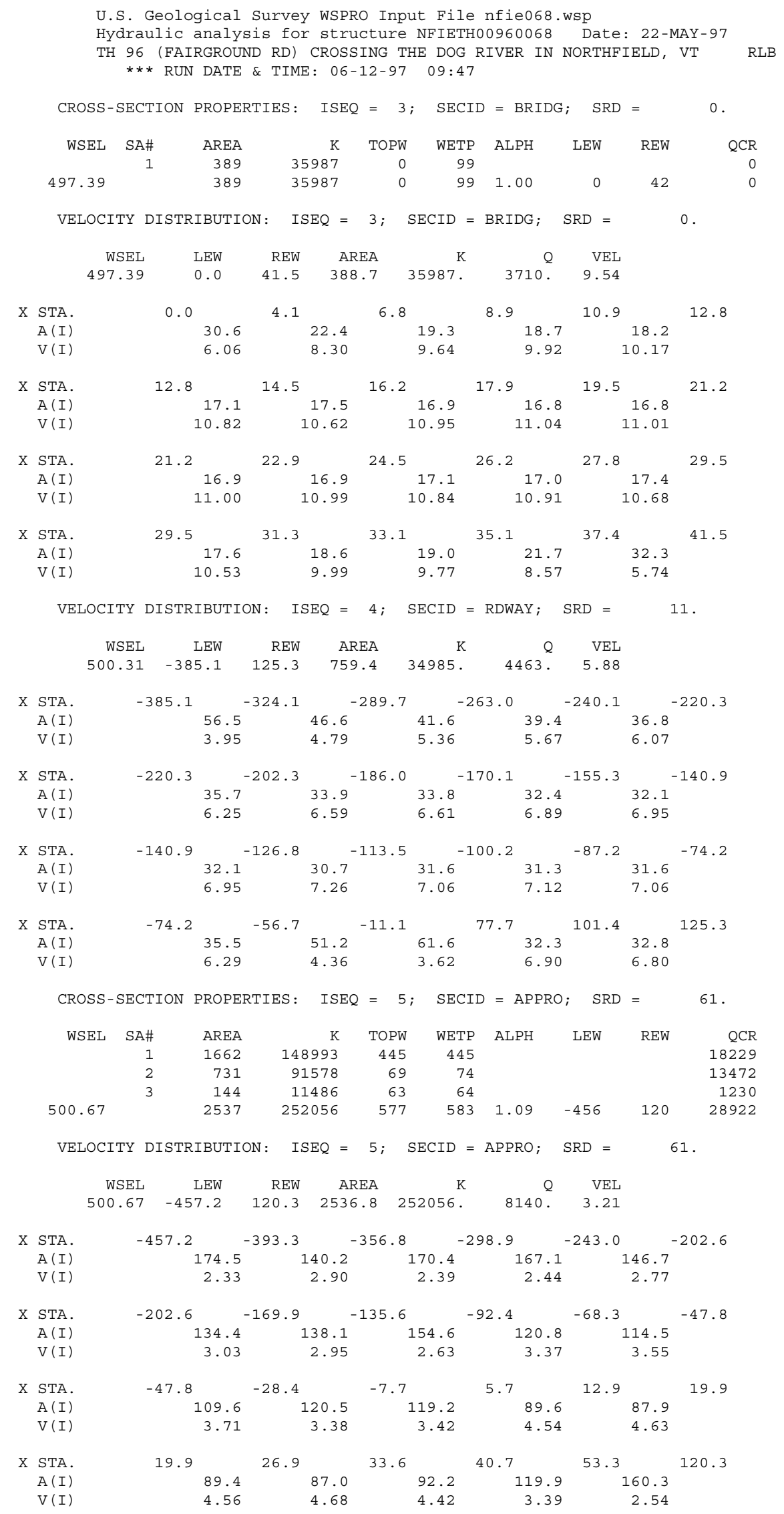


WSPRO OUTPUT FILE (continued)

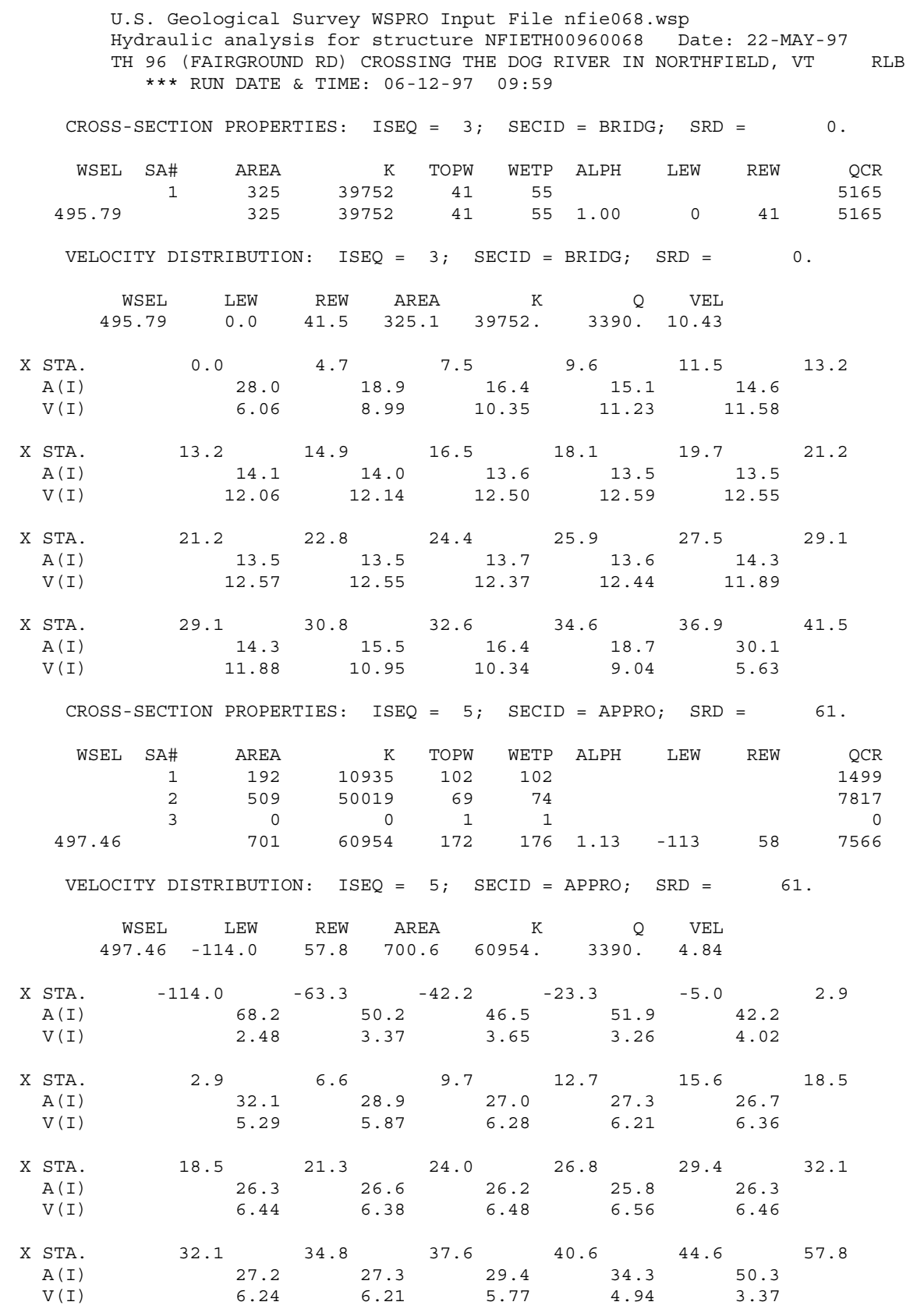


WSPRO OUTPUT FILE (continued)

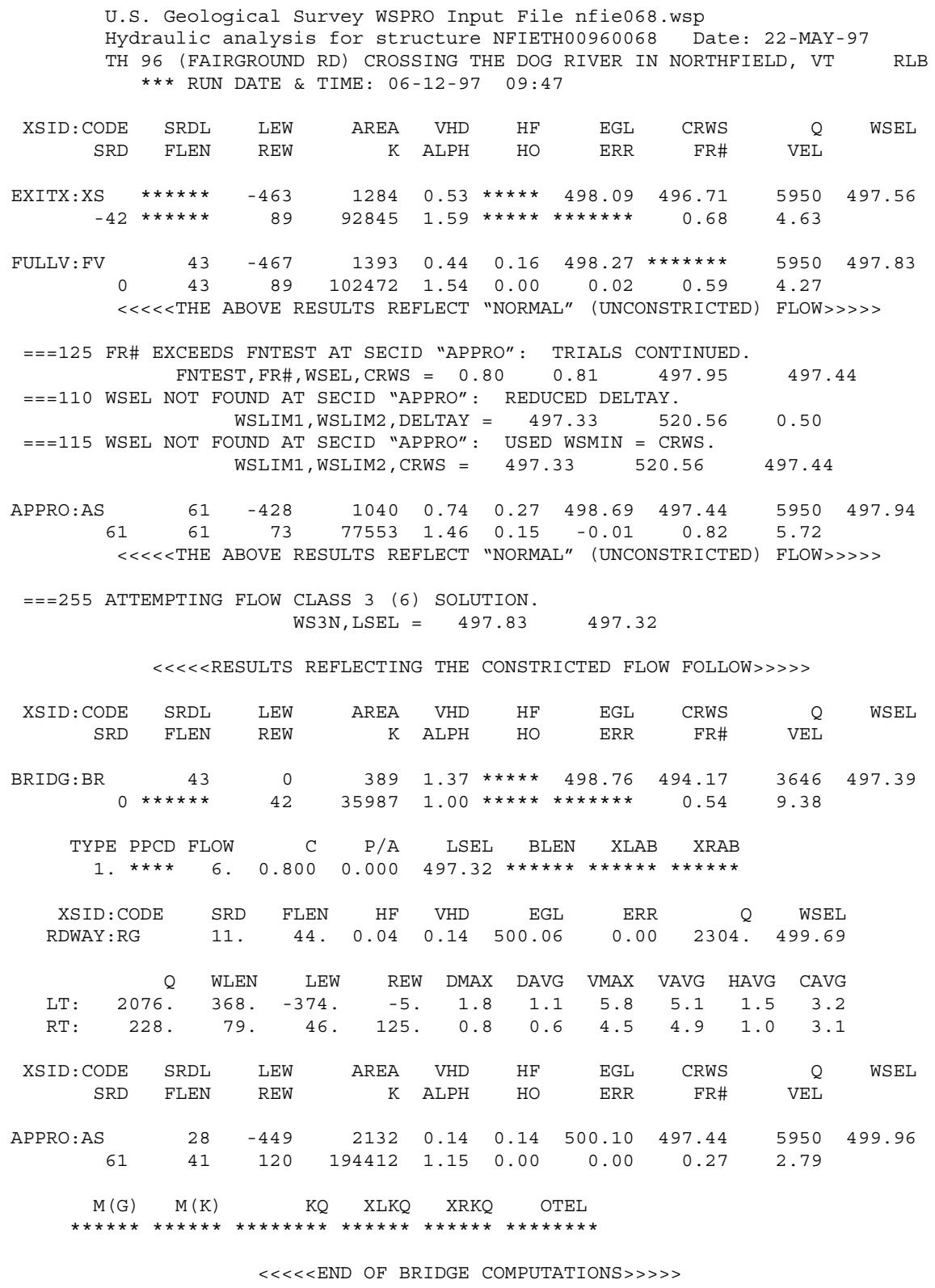

FIRST USER DEFINED TABLE.

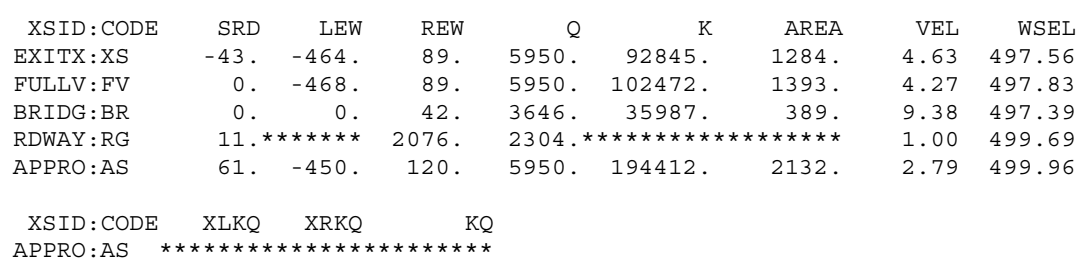

SECOND USER DEFINED TABLE.

$\begin{array}{lcrrrrrrrr}\text { XSID : CODE } & \text { CRWS } & \text { FR\# } & \text { YMIN } & \text { YMAX } & \text { HF } & \text { HO } & \text { VHD } & \text { EGL } & \text { WSEL } \\ \text { EXITX:XS } & 496.71 & 0.68 & 487.16 & 507.17 * * * * * * * * * * & 0.53 & 498.09 & 497.56 \\ \text { FULLV:FV } & * * * * * * * & 0.59 & 487.23 & 507.24 & 0.16 & 0.00 & 0.44 & 498.27 & 497.83 \\ \text { BRIDG: BR } & 494.17 & 0.54 & 487.05 & 497.39 * * * * * * * * * * & 1.37 & 498.76 & 497.39 \\ \text { RDWAY: RG } & * * * * * * * * * * * * * * & 497.85 & 520.56 & 0.04 * * * * * & 0.14 & 500.06 & 499.69 \\ \text { APPRO:AS } & 497.44 & 0.27 & 487.56 & 520.56 & 0.14 & 0.00 & 0.14 & 500.10 & 499.96\end{array}$


WSPRO OUTPUT FILE (continued)

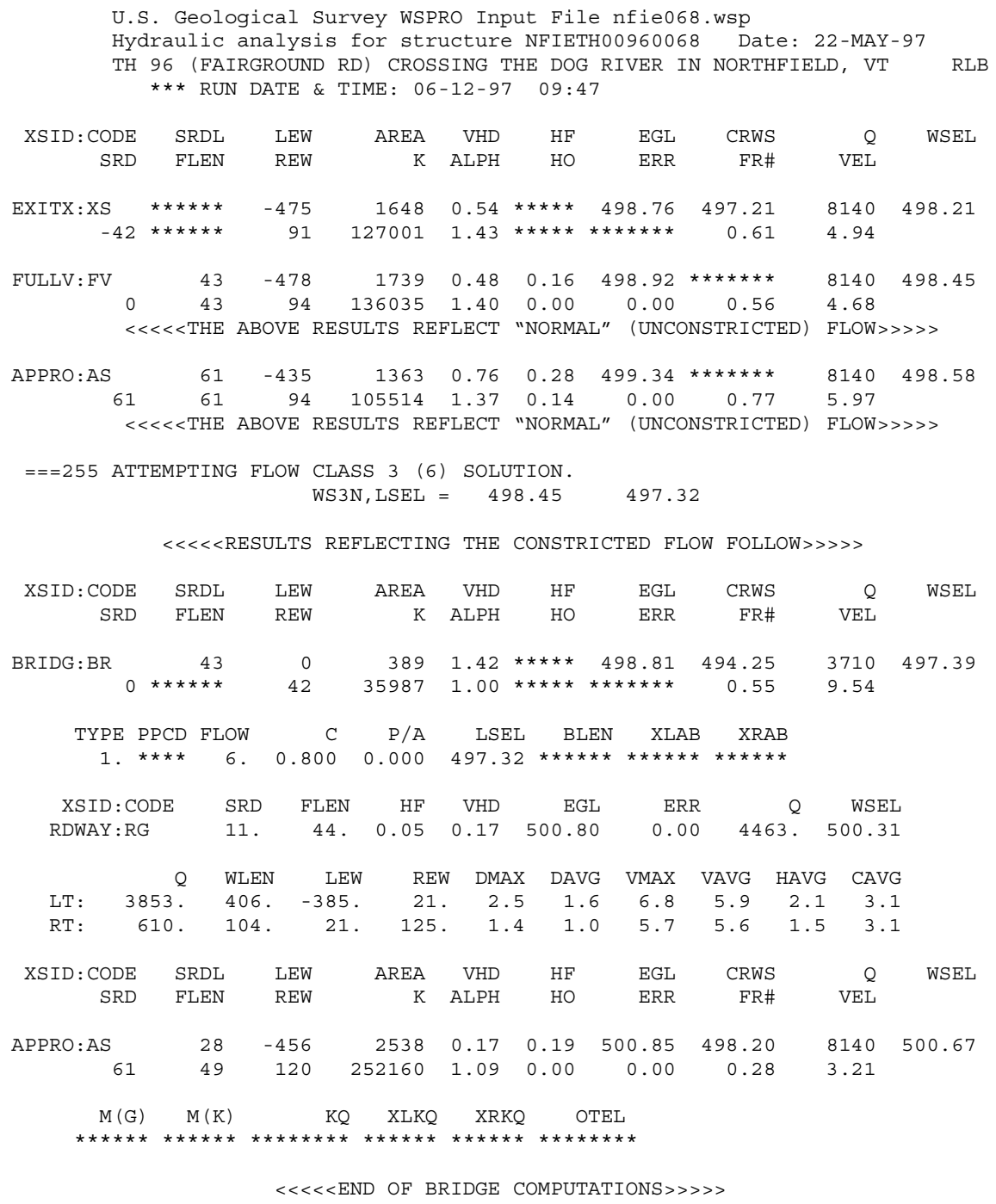

FIRST USER DEFINED TABLE.

\begin{tabular}{|c|c|c|c|c|c|c|c|c|}
\hline XSID : CODE & SRD & LEW & REW & $Q$ & $\mathrm{~K}$ & AREA & VEL & WSEL \\
\hline EXITX:XS & -43 & -476 & 91. & 8140. & 127001. & 1648. & 4.94 & 498.21 \\
\hline FULLV : FV & 0 . & -479 . & 94. & 8140. & 136035 . & 1739. & 4.68 & 498.45 \\
\hline BRIDG : BR & 0 . & 0 & 42 . & 3710 . & 35987 . & 389. & 9.54 & 497.39 \\
\hline RDWAY : RG & $11 . *$ & 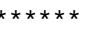 & 3853 . & 4463 . & 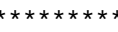 & $* * * * * *$ & 1.00 & 500.31 \\
\hline APPRO: AS & 61. & -457 & 120 & 8140. & 252160 . & 2538 . & 3.21 & 500.67 \\
\hline XSID : CODE & XLKQ & XRKQ & & & & & & \\
\hline
\end{tabular}

SECOND USER DEFINED TABLE.

\begin{tabular}{|c|c|c|c|c|c|c|c|c|c|}
\hline XSID : CODE & CRWS & FR\# & YMIN & YMAX & $\mathrm{HF}$ & $\mathrm{HO}$ & VHD & EGL & \\
\hline EXITX:XS & 497.21 & 0.61 & 487.16 & $507.17 * *$ & & & & 498.76 & \\
\hline PLLV : FV & 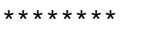 & 56 & & 07.24 & 0.16 & & 8 & & \\
\hline$R I$ & 494.25 & .55 & & $497.39 * *$ & 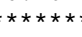 & $\star \star \star \star * *$ & .42 & 81 & \\
\hline & 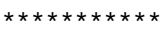 & $\star \star \star * *$ & & 20.56 & 0 & $\star \star \star \star \star *$ & & 00.80 & \\
\hline $0: A S$ & 498.20 & 0.28 & 87.56 & 520.56 & 0.19 & 0.00 & 0.17 & 00.85 & 00 \\
\hline
\end{tabular}


WSPRO OUTPUT FILE (continued)

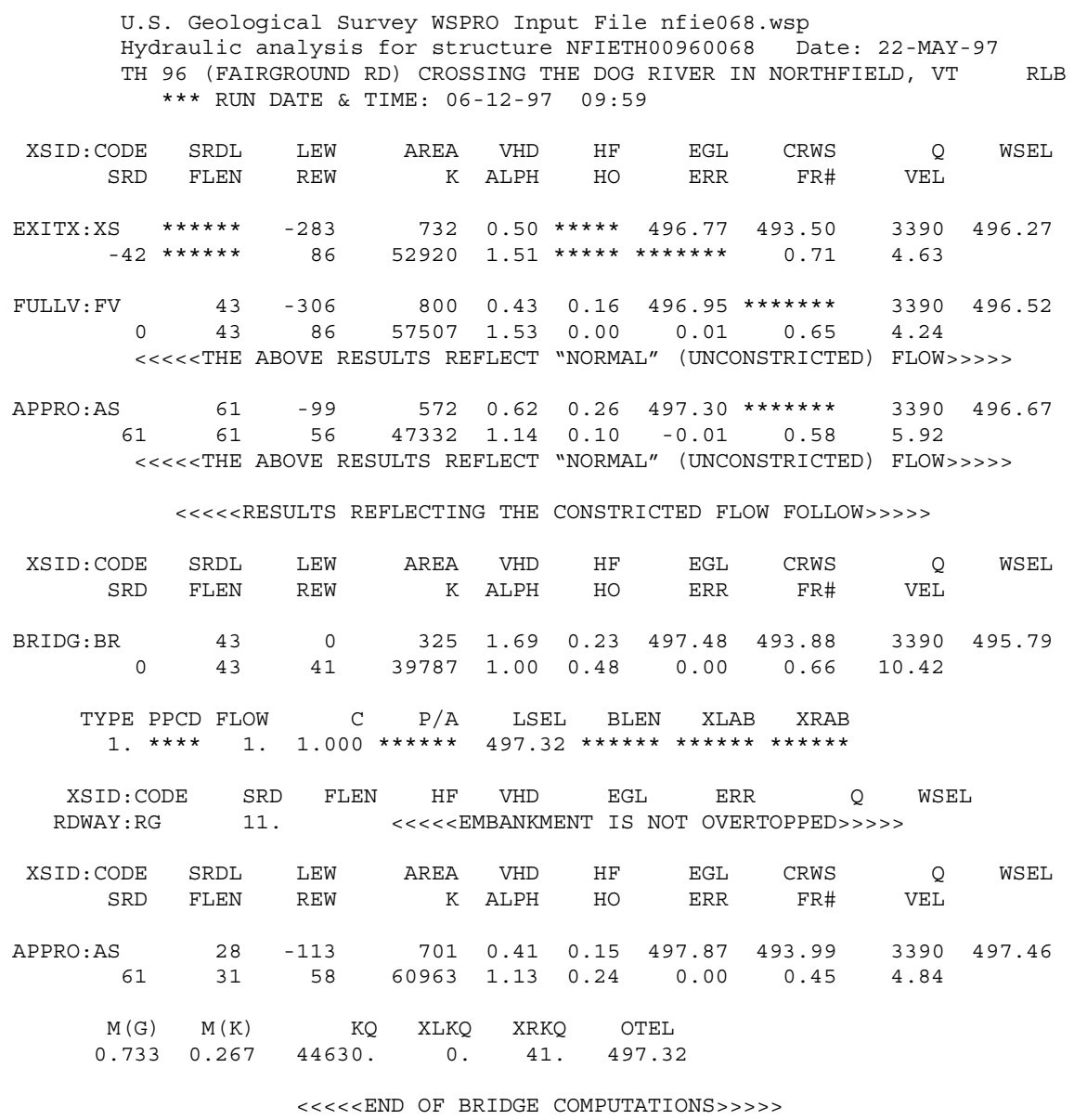

FIRST USER DEFINED TABLE.

\begin{tabular}{|c|c|c|c|c|c|c|c|c|}
\hline XSID : CODE & SRD & LEW & REW & Q & $\mathrm{K}$ & AREA & VEL & WSEL \\
\hline EXITX:XS & -43 & -284 & 86. & 3390. & 52920. & 732. & 4.63 & 496.27 \\
\hline FULLV : FV & 0 & -307. & 86. & 3390. & 57507 . & 800 & 4.24 & 496.52 \\
\hline BRIDG : BR & 0 & 0 & 41 & 3390. & 39787 . & 325. & 10.42 & 495.79 \\
\hline RDWAY : RG & \multicolumn{3}{|c|}{$11 . * * * * * * * * * * * * * *$} & \multicolumn{3}{|c|}{ 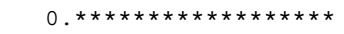 } & \multicolumn{2}{|c|}{$1.00 * * * * * * * *$} \\
\hline APPRO : AS & 61. & -114 & 58 & 3390. & 60963. & 701. & 4.84 & 497.46 \\
\hline XSID : CODE & XLKQ & $\mathrm{XRKQ}$ & & & & & & \\
\hline APPRO : AS & 0. & 41 & $4463 c$ & & & & & \\
\hline
\end{tabular}

SECOND USER DEFINED TABLE.

\begin{tabular}{|c|c|c|c|c|c|c|c|c|c|}
\hline XSID : CODI & CRWS & FR\# & YMIN & YMAX & $\mathrm{HF}$ & $\mathrm{HO}$ & VHD & EGL & WSEL \\
\hline EXITX:XS & 493.50 & 0.71 & 487.16 & 507.17 * & 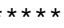 & $* \star \star \star * *$ & 0.50 & 496.77 & 496.27 \\
\hline FULLV : FV & $\star \star \star \star \star \star \star * \star *$ & 0.65 & 487.23 & 507.24 & 0.16 & 0.00 & 0.43 & 496.95 & 496.52 \\
\hline BRIDG : BR & 493.88 & 0.66 & 487.05 & 497.39 & 0.23 & 0.48 & 1.69 & 497.48 & 495.79 \\
\hline RDWAY : RG & 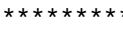 & $* * * * *$ & 497.85 & $520.56 *$ & $* * * *$ & $* * * *$ & $\star \star \star \star \star ~$ & 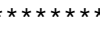 & 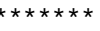 \\
\hline PPRO:AS & 493.99 & 0.45 & 487.56 & 505.76 & 0.15 & 0.24 & 0.41 & 497.87 & 497.46 \\
\hline
\end{tabular}




\section{APPENDIX C:}

\section{BED-MATERIAL PARTICLE-SIZE DISTRIBUTION}




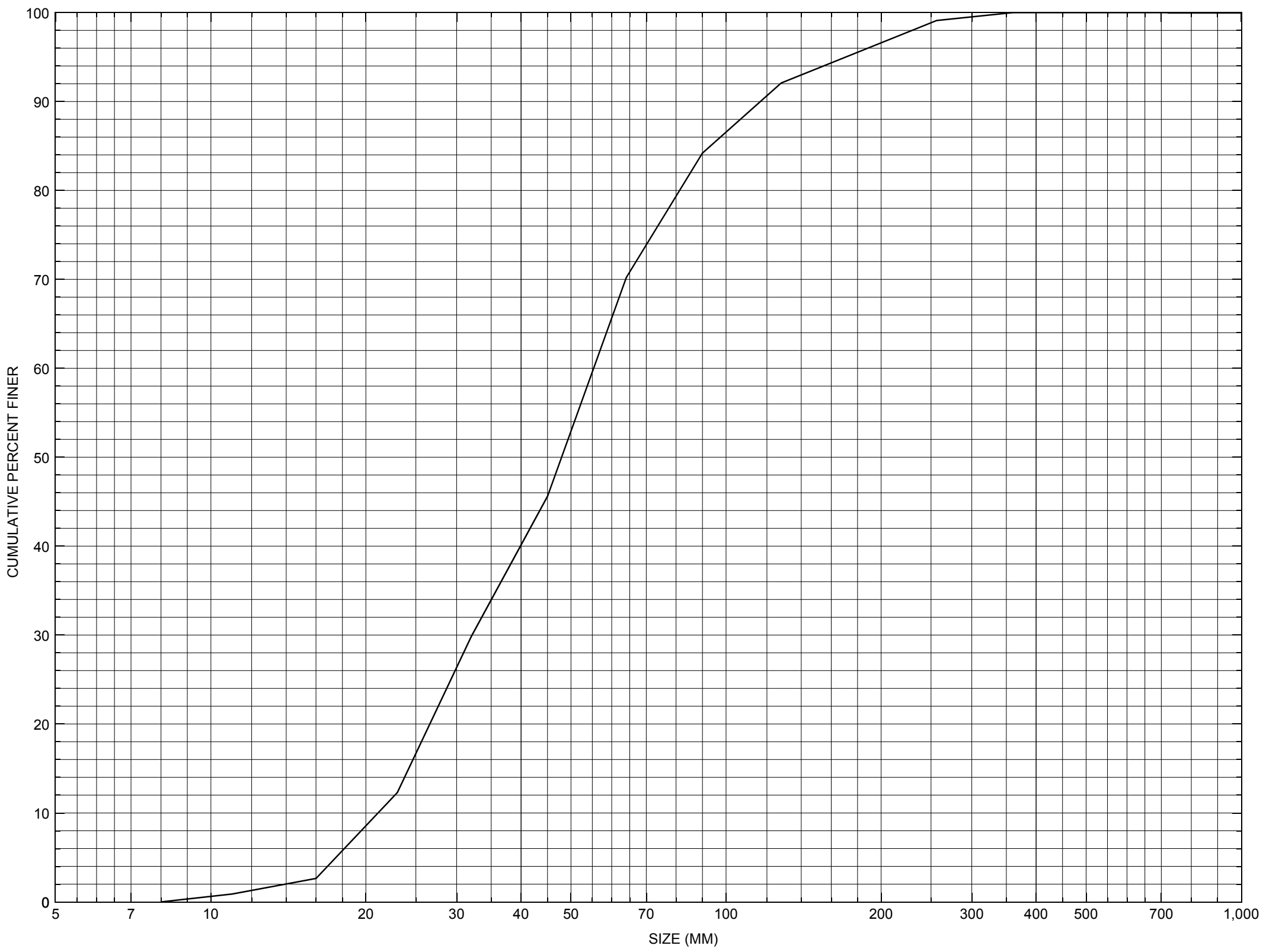

Appendix C. Bed material particle-size distribution for a pebble count in the channel approach of structure NFIETH00960068, in Northfield, Vermont. 


\section{APPENDIX D: \\ HISTORICAL DATA FORM}




\section{Structure Number NFIETH00960068}

\section{General Location Descriptive}

Data collected by (First Initial, Full last name) $\underline{\text { L. }}$. Medalie

Date $(M M / D D / Y Y) \_10 / 13 / \underline{95}$

Highway District Number $(I-2 ; n n) \underline{\mathbf{0 6}}$

Town (FIPS place code; I - 4; nnnnn) $\mathbf{5 0 2 7 5}$

Waterway (I - 6) DOG RIVER

Route Number C3096

Topographic Map Roxbury

Latitude (I - 16; nnnn.n) $\mathbf{4 4 0 7 4}$
County (FIPS county code; I - 3; nnn)

Mile marker (I - 11; nnn.nnn) $\mathbf{0 0 0 0 0 0}$

Road Name (I - 7): Fairground Road

Vicinity (I - 9) 0.01 MI TO JCT W VT12A

Hydrologic Unit Code: $\mathbf{0 2 0 1 0 0 0 3}$

Longitude (i - 17; nnnnn.n) $\mathbf{7 2 4 0 0}$

\section{Select Federal Inventory Codes}

FHWA Structure Number (I - 8) $\mathbf{1 0 1 2 1 3 0 0 6 8 1 2 1 3}$

Maintenance responsibility $(I-21 ; n n) \_$03 $\quad$ Maximum span length $(I-48 ; n n n n) \underline{\mathbf{0 0 4 3}}$

Year built (I - 27; YYYY) 1960

Structure length (I - 49; nnnnnn) $\underline{\mathbf{0 0 0 0 4 5}}$

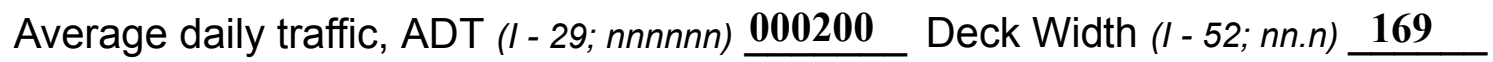

Year of ADT (I - 30; YY) $\mathbf{9 2}$

Channel \& Protection $(I-61 ; n) \underline{5}$

Opening skew to Roadway $(I-34 ; n n) \quad \mathbf{0 0}$

Waterway adequacy $(I-71 ; n)$

Operational status $(I-41 ; X) \quad \mathbf{A}$

Underwater Inspection Frequency $(I-92 B ; X Y Y) \_\mathbf{N}$

Structure type (I - 43; nnn) $\mathbf{3 0 2}$

Year Reconstructed (I - 106) $\mathbf{0 0 0 0}$

Approach span structure type $(I-44 ; n n n) \quad \mathbf{0 0 0}$

Clear span (nnn.n ft) _ _

Number of spans (I - 45; nnn) $\mathbf{0 0 1}$

Vertical clearance from streambed (nnn.n ft) -

Number of approach spans (I - 46; nnnn) $\mathbf{0 0 0 0}$

Waterway of full opening $\left(n n n . n \mathrm{ft}^{2}\right)$

Comments:

According to the structural inspection report dated 8/22/94, the deck is wood planks and wood runners. The abutments and wingwalls are concrete. The RABUT has a large concrete footing, and each abutment has wood plank backwalls. The RABUT has a random fine vertical crack and small leak just right of center, there are also a few minor fine cracks in the LABUT and wingwalls. Some boulder riprap is present around the ends of both right wingwalls. Channel scour is noted as normal. The embankments show signs of past erosion. Minor gravel bars and debris are noted. 


\section{Bridge Hydrologic Data}

Is there hydrologic data available? $\underline{\mathbf{N}}$ if No, type ctrl-n $h \quad$ VTAOT Drainage area $\left(m i^{2}\right)$ : -

Terrain character:

Stream character \& type: -

Streambed material:

Discharge Data (cfs):

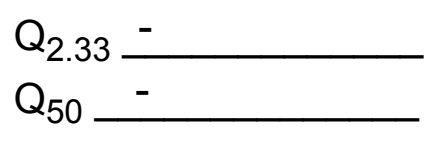

Record flood date $(M M / D D / Y Y):-{ }^{\prime}-$
Estimated Discharge $(c f s):-$

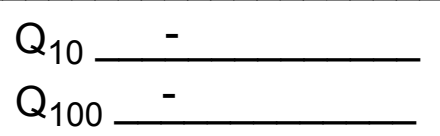

$\mathrm{Q}_{25}$

Water surface elevation $(f t):-$ $(\mathrm{ft} / \mathrm{s}):$

Ice conditions (Heavy, Moderate, Light) : -

Debris (Heavy, Moderate, Light):

The stage increases to maximum highwater elevation (Rapidly, Not rapidly):

The stream response is (Flashy, Not flashy):

Describe any significant site conditions upstream or downstream that may influence the stream's stage: -

Watershed storage area (in percent):

The watershed storage area is: - (1-mainly at the headwaters; 2- uniformly distributed; 3-immediatly upstream oi the site)

Water Surface Elevation Estimates for Existing Structure:

\begin{tabular}{|l|l|l|l|l|l|}
\hline Peak discharge frequency & $Q_{2.33}$ & $Q_{10}$ & $Q_{25}$ & $Q_{50}$ & $Q_{100}$ \\
Water surface elevation (ft)) & - & - & - & - & - \\
Velocity (ft/sec) & - & - & - & - & - \\
\hline
\end{tabular}

Long term stream bed changes: -

Is the roadway overtopped below the $\mathrm{Q}_{100}$ ? (Yes, No, Unknown): $\mathbf{U}$ Frequency: -

Relief Elevation $(f t)$ :

Discharge over roadway at $Q_{100}\left(f t^{3} / \mathrm{sec}\right)$ :

Are there other structures nearby? (Yes, No, Unknown): Upstream distance (miles): Town: If No or Unknown, type ctrl-n os Highway No. :Structure No. : Year Built:

Clear span (ft): Clear Height $(f t)$ : Full Waterway $\left(f^{2}\right)$ : 
Downstream distance (miles): Town: Year Built:

Highway No. : Structure No. : Structure Type:

Clear span (ft): Clear Height $(f t)$ : Full Waterway $\left(f^{2}\right)$ : -

Comments:

\section{USGS Watershed Data}

Watershed Hydrographic Data

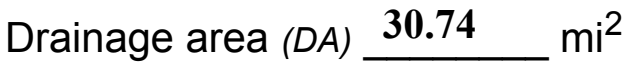
Lake/pond/swamp area 0.03 $\mathrm{mi}^{2}$

Watershed storage (ST) 0.1

Bridge site elevation 750 $\mathrm{ft}$ $\%$

Main channel length 9.21 $\mathrm{mi}$ $10 \%$ channel length elevation $\mathbf{7 7 0}$ $\mathrm{ft} \quad 85 \%$ channel length elevation $\mathrm{ft}$

Main channel slope $(S)$

(S) 125.95 $\mathrm{ft} / \mathrm{mi}$

Watershed Precipitation Data

Average site precipitation in Average headwater precipitation in

Maximum 2yr-24hr precipitation event $(124,2)$ in

Average seasonal snowfall (Sn) $\mathrm{ft}$ 


\section{Bridge Plan Data}

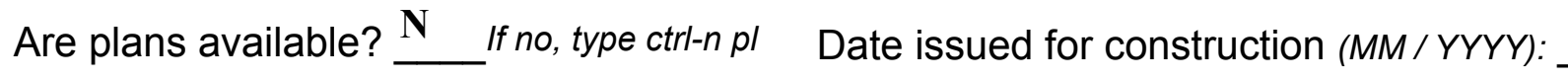

Project Number -

Minimum channel bed elevation:

Low superstructure elevation: USLAB DSLAB USRAB DSRAB Benchmark location description:

-

Reference Point (MSL, Arbitrary, Other):

Datum (NAD27, NAD83, Other):

Foundation Type:

(1-Spreadfooting; 2-Pile; 3- Gravity; 4-Unknown)

If 1: Footing Thickness _ _ _ Footing bottom elevation: -

If 2: Pile Type: (1-Wood; 2-Steel or metal; 3-Concrete)

Approximate pile driven length: -

If 3 : Footing bottom elevation:

Is boring information available? If no, type ctrl-n bi Number of borings taken:

Foundation Material Type: (1-regolith, 2-bedrock, 3-unknown)

Briefly describe material at foundation bottom elevation or around piles:

Comments:

- 


\section{Cross-sectional Data}

Is cross-sectional data available? $\underline{\mathbf{Y}}$ If no, type ctrl-n xs

Source (FEMA, VTAOT, Other)? HUD

Comments:

\begin{tabular}{|l|l|l|l|l|l|l|l|l|l|l|l|}
\hline Station & $\mathbf{8 6 6}$ & $\mathbf{8 7 0}$ & $\mathbf{8 9 0}$ & $\mathbf{9 1 0}$ & $\mathbf{9 1 1}$ & - & - & - & - & - & - \\
\hline Feature & LCL & - & - & - & LCR & - & - & - & - & - & - \\
\hline $\begin{array}{l}\text { Low cord } \\
\text { elevation }\end{array}$ & $\mathbf{7 5 7 . 5}$ & $\mathbf{7 5 7 . 5}$ & $\mathbf{7 5 7 . 5}$ & $\mathbf{7 5 7 . 5}$ & $\mathbf{7 5 7 . 5}$ & - & - & - & - & - & - \\
\hline $\begin{array}{l}\text { Bed } \\
\text { elevation }\end{array}$ & - & $\mathbf{7 4 6 . 1}$ & $\mathbf{7 4 6 . 4}$ & $\mathbf{7 4 8 . 0}$ & - & - & - & - & - & - & - \\
\hline $\begin{array}{l}\text { Low cord to } \\
\text { bed length }\end{array}$ & - & $\mathbf{1 1 . 4}$ & $\mathbf{1 1 . 1}$ & $\mathbf{9 . 5}$ & - & - & - & - & - & - & - \\
\hline Station & - & - & - & - & - & - & - & - & - & - & - \\
\hline Feature & - & - & - & - & - & - & - & - & - & - & - \\
\hline $\begin{array}{l}\text { Low cord } \\
\text { elevation }\end{array}$ & - & - & - & - & - & - & - & - & - & - & - \\
\hline $\begin{array}{l}\text { Bed } \\
\text { elevation }\end{array}$ & - & - & - & - & - & - & - & - & - & - & - \\
\hline $\begin{array}{l}\text { Low cord to } \\
\text { bed length }\end{array}$ & - & - & - & - & - & - & - & - & - & - & - \\
\hline
\end{tabular}

Source (FEMA, VTAOT, Other)?

Comments: -

\begin{tabular}{|l|l|l|l|l|l|l|l|l|l|l|l|}
\hline Station & - & - & - & - & - & - & - & - & - & - & - \\
\hline Feature & - & - & - & - & - & - & - & - & - & - & - \\
\hline $\begin{array}{l}\text { Low cord } \\
\text { elevation }\end{array}$ & - & - & - & - & - & - & - & - & - & - & - \\
\hline $\begin{array}{l}\text { Bed } \\
\text { elevation }\end{array}$ & - & - & - & - & - & - & - & - & - & - & - \\
\hline $\begin{array}{l}\text { Low cord to } \\
\text { bed length }\end{array}$ & - & - & - & - & - & - & - & - & - & - & - \\
\hline Station & - & - & - & - & - & - & - & - & - & - & - \\
\hline Feature & - & - & - & - & - & - & - & - & - & - & - \\
\hline $\begin{array}{l}\text { Low cord } \\
\text { elevation }\end{array}$ & - & - & - & - & - & - & - & - & - & - & - \\
\hline $\begin{array}{l}\text { Bed } \\
\text { elevation }\end{array}$ & - & - & - & - & - & - & - & - & - & - & - \\
\hline $\begin{array}{l}\text { Low cord to } \\
\text { bed length }\end{array}$ & - & - & - & - & - & - & - & - & - & - & - \\
\hline
\end{tabular}




\section{APPENDIX E: \\ LEVEL I DATA FORM}


U. S. Geological Survey

Bridge Field Data Collection and Processing Form

Qa/Qc Check by: JD Date: $\mathbf{0 6 / 1 1 / 9 7}$

\section{Structure Number}

NORTTH00960068

Computerized by: JD Date: 06/11/97

Reviewd by: $\quad \mathbf{R B}$ Date: $\underline{06 / 16 / 97}$

\section{A. General Location Descriptive}

1. Data collected by (First Initial, Full last name) R. BURNS

2. Highway District Number 06

County WASHINGTON (023)

Mile marker $\underline{0}$

Waterway (I - 6) DOG RIVER

Town NORTHFIELD (50275)

Route Number $\mathbf{C 3 0 9 6}$

Road Name FAIRGROUND ROAD

Hydrologic Unit Code: $\mathbf{0 2 0 1 0 0 0 3}$

3. Descriptive comments:

This structure is located 0.01 mile from the junction with State Route 12A.

\section{B. Bridge Deck Observations}
4. Surface cover... LBUS 4
RBUS 6
LBDS 4
RBDS 4
Overall 4

(2b us, ds,lb,rb: 1- Urban; 2- Suburban; 3- Row crops; 4- Pasture; 5- Shrub- and brushland; 6- Forest; 7- Wetland)
5. Ambient water surface... US 2
UB 2
DS 2
(1- pool; 2- riffle)

6. Bridge structure type 1 (1- single span; 2- multiple span; 3- single arch; 4- multiple arch; 5-cylindrical culvert; 6- box culvert; or 7- other)
7. Bridge length $\mathbf{4 5}$
(feet)
Span length $\underline{43}$
(feet)
Bridge width 16.9 (feet)

\section{Road approach to bridge:}
8. LB 1 RB 1
( 0 even, 1- lower, 2- higher)
9. LB
RB 1
(1-Paved, 2- Not paved)

10. Embankment slope (run / rise in feet / foot)

US left

US right

\begin{tabular}{|l|l|l|l|}
\hline \multicolumn{2}{|c|}{ Protection } & \multirow{2}{*}{ 13.Erosion } & 14.Severity \\
\cline { 1 - 2 } 11.Type & 12.Cond. & & \\
\hline
\end{tabular}

LBUS

RBUS

RBDS

LBDS

\begin{tabular}{l|l|}
\hline 2 & - \\
\hline 2 & 1 \\
\hline 0 & - \\
\hline
\end{tabular}

\begin{tabular}{l}
\hline 0 \\
\hline 0 \\
\hline 0
\end{tabular}

Bank protection types: 0- none; 1- $<12$ inches,

2- $<36$ inches; 3- $<48$ inches;

4- < 60 inches; 5- wall / artificial levee

Bank protection conditions: 1- good; 2- slumped;

3- eroded; 4- failed

Erosion: 0 - none; 1- channel erosion; 2 -

road wash; 3- both; 4- other

Erosion Severity: 0 - none; 1- slight; 2- moderate; 3- severe

\section{Channel approach to bridge (BF):}

15. Angle of approach: 0

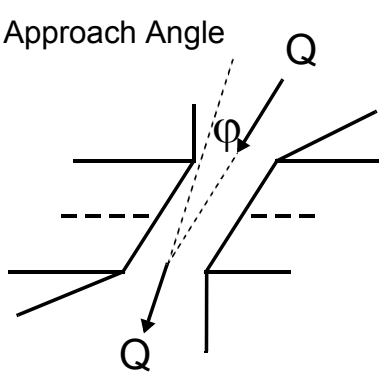

16. Bridge skew: $\mathbf{0}$

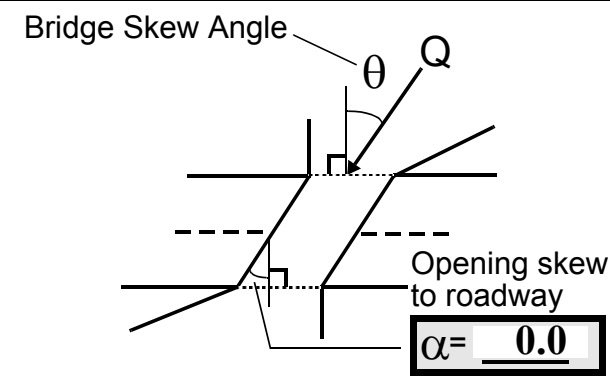

17. Channel impact zone 1 :

Where? RB (LB, RB)

Exist? $\underline{\mathbf{Y}}(\mathrm{Y}$ or $N)$

Range? 130 feet US

Severity 1

Channel impact zone 2:

(US, UB, DS) to 100 feet $\underline{\mathbf{U S}}$

Where? RB (LB, RB)

Exist? $\mathbf{Y}(\mathrm{Y}$ or $N)$

Severity $\underline{2}$

Range? $\underline{\mathbf{1 8 0}}$ feet $\underline{\mathbf{D S}}$ (US, UB, DS) to $\underline{\mathbf{2 1 0}}$ feet $\underline{\mathbf{D S}}$

Impact Severity: 0- none to very slight; 1-Slight; 2- Moderate; 3- Severe 
18. Bridge Type: 1a

1a- Vertical abutments with wingwalls

1 b- Vertical abutments without wingwalls

2- Vertical abutments and wingwalls, sloping embankment Wingwalls perpendicular to abut. face

3- Spill through abutments

4- Sloping embankment, vertical wingwalls and abutments

Wingwall angle less than $90^{\circ}$.

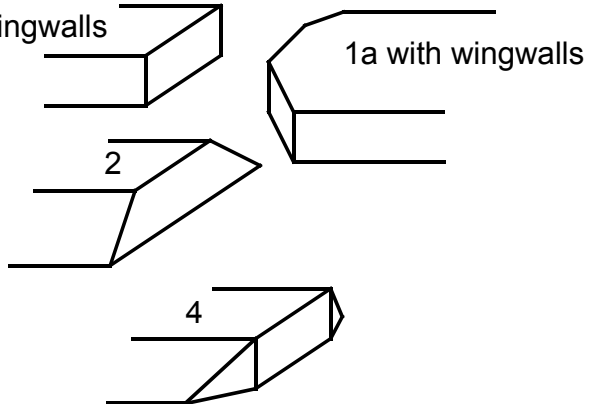

19. Bridge Deck Comments (surface cover variations, measured bridge and span lengths, bridge type variations, approach overflow width, etc.)

4. The left banks have trees along the immediate banks and tall grass on the overbanks which changes to lawns, both upstream and downstream. The downstream right bank has tall grass on the streamward side of VT 12A, and a lawn on the bankward side. The upstream right bank has trees along the road embankment and on the bankward side of VT 12A.

11. The right bank road embankment protection consists of large concrete blocks at the ends of each wingwall. 7. Values are from the VT AOT database. The measured bridge length is forty four and six tenths feet. The measured span length is forty one and four tenths feet. The width is seventeen and one tenth feet.

\section{Upstream Channel Assessment}

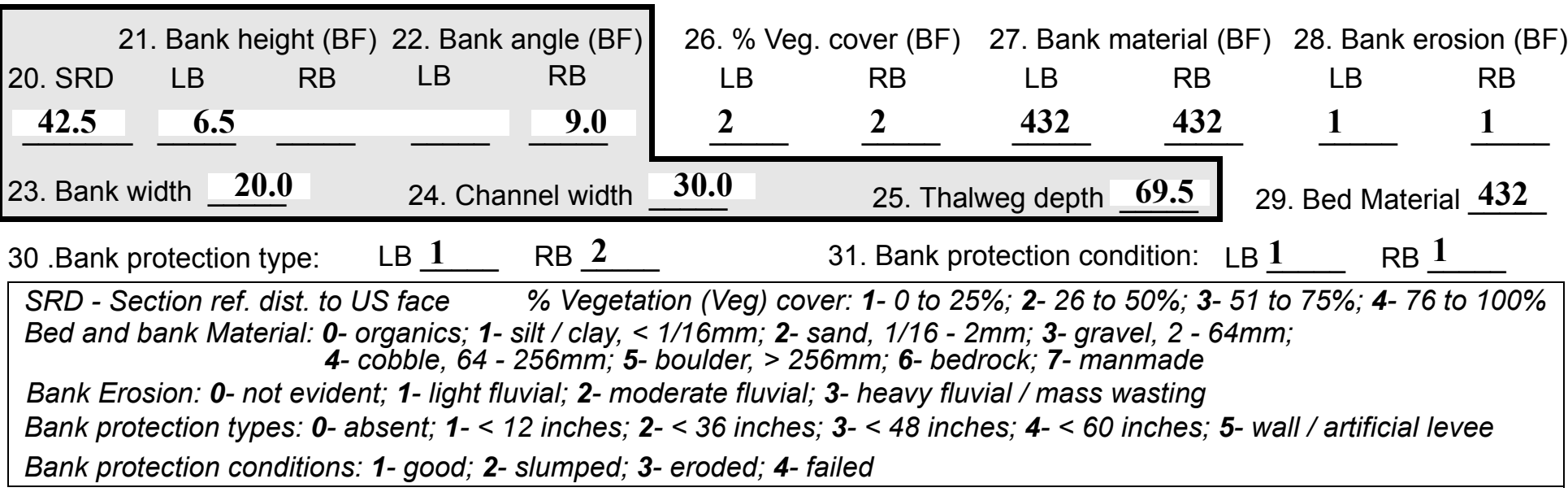

32. Comments (bank material variation, minor inflows, protection extent, etc.):

30. The right bank protection is concrete fragments that extend from twenty eight to seven feet upstream.

The left bank protection is dumped stone which has become vegetated with bushes. It extends from twenty eight feet upstream to eight feet upstream.

There is a bedrock outcrop on the upstream right bank from two hundred feet upstream to fifty five feet upstream. 
33.Point/Side bar present? $\mathbf{N}(Y$ or $N$. if $N$ type ctrl-n pb)34. Mid-bar distance: -

35. Mid-bar width: -

36. Point bar extent: feet (US, UB) to feet (US, UB, DS) positioned $\%$ LB to $\% \mathrm{RB}$

37. Material: -

38. Point or side bar comments (Circle Point or Side; Note additional bars, material variation, status, etc.):

NO POINT BARS

39. Is a cut-bank present? $\underline{\mathbf{Y}}$ (Y or if $N$ type ctrl-n $c b)$

40. Where? $\mathbf{L B}$ (LB or RB)

41. Mid-bank distance: $\mathbf{3 5}$

42. Cut bank extent: 28

\section{(US,} feet $\underline{\mathbf{U S}}$ (US, UB, DS)

43. Bank damage: 1 (1- eroded and/or creep; 2- slip failure; 3- block failure)

44. Cut bank comments (eg. additional cut banks, protection condition, etc.):

Some roots are exposed on this cut bank. There are two additional cut-banks. The left bank cut bank extends from ninety feet upstream to eighty five feet upstream. The right bank cut bank which is between two bedrock outcrops extends from one hundred and thirty feet upstream to one hundred feet upstream.

\section{Is channel scour present? $\mathbf{N}$ ( $Y$ or if $N$ type ctrl-n cs)}

47. Scour dimensions: Length Width Depth : 46. Mid-scour distance: -

48. Scour comments (eg. additional scour areas, local scouring process, etc.):

NO CHANNEL SCOUR

49. Are there major confluences? $\mathbf{N}$

51. Confluence 1: Distance Confluence 2: Distance 52. Enters on Enters on 54. Confluence comments (eg. confluence name):

NO MAJOR CONFLUENCES
50. How many? -

53. Type(1- perennial; 2- ephemeral)

Type (1- perennial; 2- ephemeral)

\section{Under Bridge Channel Assessment}

55. Channel restraint (BF)? LB 2

\begin{tabular}{|ccccc}
\hline \multicolumn{2}{|c}{56. Height (BF) } & \multicolumn{3}{c}{57 Angle (BF) } \\
LB & RB & LB & RB \\
$\mathbf{3 8 . 0}$ & & & $\mathbf{1 . 0}$ & \\
\hline
\end{tabular}
(1- natural bank; 2- abutment; 3- artificial levee)

58. Bank width (BF) 59. Channel width (Amb) -

61. Material (BF)

LB RB

$\underline{2} \quad 7$
62. Erosion (BF)

LB RB

7

63. Bed Material -

Bed and bank Material: 0- organics; 1- silt / clay, < 1/16mm; 2- sand, 1/16 - 2mm; 3- gravel, 2 - 64mm; 4- cobble, 64 - 256mm; 5- boulder, > 256mm; 6- bedrock; 7- manmade

Bank Erosion: 0- not evident; 1- light fluvial; 2- moderate fluvial; 3- heavy fluvial / mass wasting

64. Comments (bank material variation, minor inflows, protection extent, etc.):

432

There is sand along the left abutment that is part of the bank, but at bank-full discharge the abutment would act as a restraint and protrude. 
65. Debris and Ice Is there debris accumulation?

67. Debris Potential ( 1- Low; 2- Moderate; 3- High)

69. Is there evidence of ice build-up? 1 (Y or N)

70. Debris and Ice Comments:
$(Y$ or $N)$ 66. Where? $\mathbf{N}$

68. Capture Efficiency 1

(1- Upstream; 2- At bridge; 3-Both)

Ice Blockage Potential $\mathbf{N}$
(1-Low; 2- Moderate; 3- High)

(1-Low; 2- Moderate; 3- High) 1

\begin{tabular}{|l|c|c|c|c|c|c|c|c|}
\hline Abutments & $\begin{array}{c}71 . \text { Attack } \\
\angle \text { (BF) }\end{array}$ & $\begin{array}{c}\text { 72. Slope } \angle \\
\text { (Qmax) }\end{array}$ & $\begin{array}{c}\text { 73. Toe } \\
\text { loc. (BF) }\end{array}$ & $\begin{array}{c}\text { 74. Scour } \\
\text { Condition }\end{array}$ & $\begin{array}{c}75 . \text { Scour } \\
\text { depth }\end{array}$ & $\begin{array}{c}\text { 76. Exposure } \\
\text { depth }\end{array}$ & 77. Material & 78. Length \\
\hline LABUT & & - & $\mathbf{9 0}$ & $\mathbf{2}$ & $\mathbf{0}$ & - & - & $\mathbf{9 0 . 0}$ \\
\hline RABUT & $\mathbf{1}$ & $\mathbf{0}$ & $\mathbf{9 0}$ & & & $\mathbf{2}$ & $\mathbf{2}$ & $\mathbf{4 1 . 5}$ \\
\hline
\end{tabular}

Pushed: $L B$ or RB

Toe Location (Loc.): 0- even, 1- set back, 2- protrudes

Scour cond.: 0- not evident; 1- evident (comment); 2- footing exposed; 3-undermined footing; 4- piling exposed; 5- settled; 6- failed

Materials: 1- Concrete; 2- Stone masonry or drywall; 3- steel or metal; 4- wood

79. Abutment comments (eg. undermined penetration, unusual scour processes, debris, etc.):

0

2

1

The right abutment footing is two feet thick.

80. Wingwalls:

$\begin{array}{lllll}\text { Exist? Material? } & \text { Scour } & \text { Scour Exposure } & \text { Angle? Length? } \\ & \text { Condition? depth? } & \text { depth? } & & \end{array}$

USLWW:

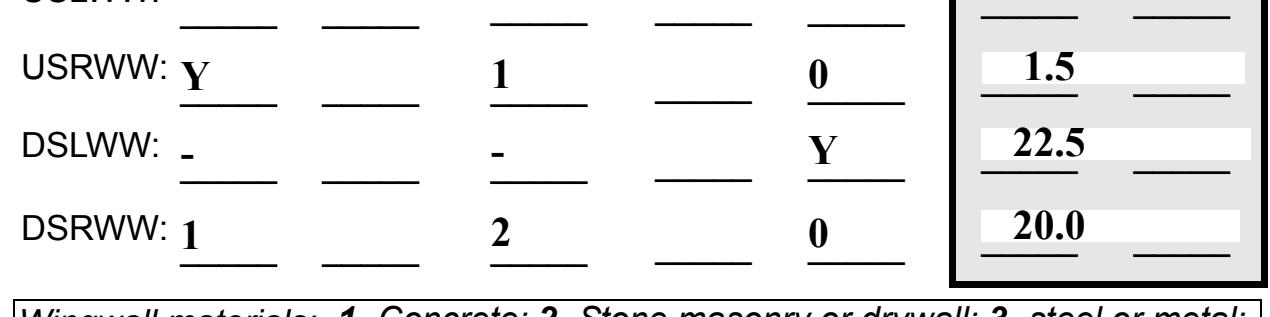

Wingwall materials: 1- Concrete; 2- Stone masonry or drywall; 3- steel or metal; 4- wood

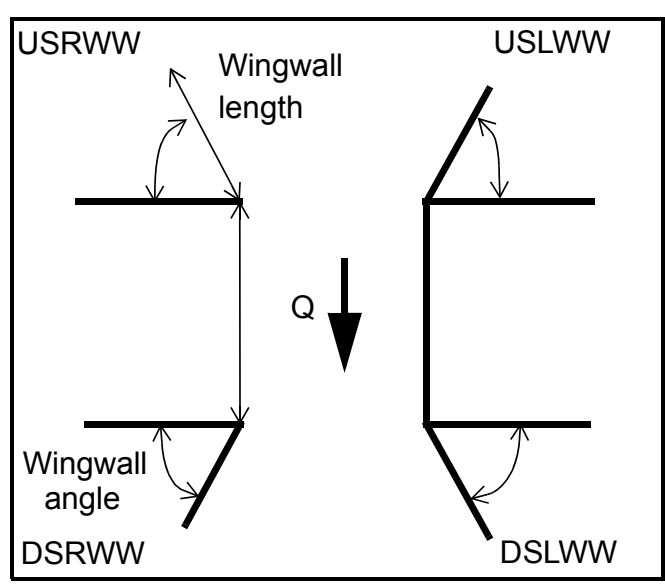

82. Bank / Bridge Protection:

\begin{tabular}{|l|l|l|l|l|l|l|l|l|}
\hline Location & USLWW & USRWW & LABUT & RABUT & LB & RB & DSLWW & DSRWW \\
\hline Type & $\mathbf{1 . 2 5}$ & $\mathbf{0}$ & $\mathbf{Y}$ & $\mathbf{0}$ & - & $\mathbf{1}$ & - & - \\
\hline Condition & $\mathbf{Y}$ & - & $\mathbf{1}$ & $\mathbf{1 . 5}$ & - & $\mathbf{2}$ & - & - \\
\hline Extent & $\mathbf{1}$ & - & $\mathbf{2}$ & $\mathbf{0}$ & $\mathbf{2}$ & $\mathbf{0}$ & $\mathbf{0}$ & - \\
\hline
\end{tabular}

Bank / Bridge protection types: 0- absent; 1- < 12 inches; 2- < 36 inches; 3- < 48 inches; 4- < 60 inches; 
83. Wingwall and protection comments (eg. undermined penetration, unusual scour processes, etc.):

-
-
-
-
-
0
-
-
2
1
3

\section{Piers:}

84. Are there piers? Th (Y or if $N$ type ctrl-n pr)

\begin{tabular}{|l|l|l|l|l|l|l|l|}
\hline \multirow{2}{*}{$\begin{array}{l}85 . \\
\text { Pier no. }\end{array}$} & \multicolumn{3}{|c|}{ width (w) feet } & \multicolumn{5}{c|}{ elevation (e) feet } \\
\cline { 2 - 8 } & w1 & w2 & w3 & e@w1 & e@w2 & e@w3 \\
\hline Pier 1 & & & & $\mathbf{4 5 . 0}$ & $\mathbf{1 5 . 5}$ & $\mathbf{4 5 . 0}$ \\
\hline Pier 2 & & & & $\mathbf{1 8 . 0}$ & $\mathbf{4 0 . 0}$ & $\mathbf{1 5 . 5}$ \\
\hline Pier 3 & & & - & $\mathbf{6 0 . 0}$ & $\mathbf{1 4 . 0}$ & - \\
\hline Pier 4 & - & - & - & - & - & - \\
\hline
\end{tabular}

\begin{tabular}{|l|l|l|l|l|}
\hline Level 1 Pier Descr. & \multicolumn{1}{|c|}{1} & \multicolumn{1}{|c|}{2} & \multicolumn{1}{|c|}{3} & \multicolumn{1}{|c|}{} \\
\hline 86. Location (BF) & e & tected & the & the \\
\hline 87. Type & upst & with & mid- & foot- \\
\hline 88. Material & ream & con- & dle & ings. \\
\hline 89. Shape & and & crete & of & The \\
\hline 90. Inclined? & dow & bloc & the & upst \\
\hline 91. Attack $\angle$ (BF) & nstre & ks & wing & ream \\
\hline 92. Pushed & am & and & walls & and \\
\hline 93. Length (feet) & - & - & - & - \\
\hline 94. \# of piles & right & stone & to & dow \\
\hline 95. Cross-members & wing & that & the & nstre \\
\hline 96. Scour Condition & walls & exte & ends, & am \\
\hline 97. Scour depth & are & nd & cov- & right \\
\hline 98. Exposure depth & pro- & from & ering & wing \\
\hline
\end{tabular}

LFP, LTB, LB, MCL, MCM, MCR, RB, RTB, RFP

1- Solid pier, 2- column, 3- bent

1-Wood; 2- concrete; 3- metal; 4- stone

1- Round; 2- Square; 3- Pointed

Y-yes; $N-$ no

$L B$ or $R B$

0- none; 1- laterals; 2- diagonals; 3- both

0- not evident; 1- evident (comment);

2- footing exposed; 3- piling exposed;

4- undermined footing; 5- settled; 6- failed 
99. Pier comments (eg. undermined penetration, protection and protection extent, unusual scour processes, etc.): walls maximum exposure depths are measured at the wingwall abutment corners.

$\mathbf{N}$

100.

\section{E. Downstream Channel Assessment}

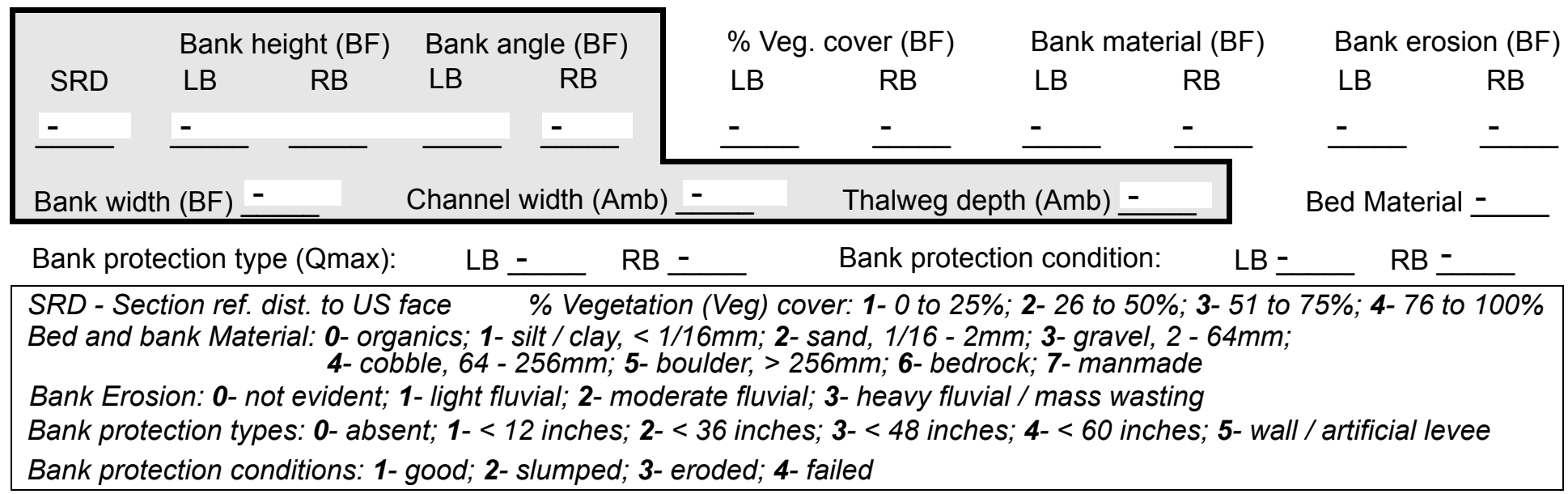

Comments (eg. bank material variation, minor inflows, protection extent, etc.):

$-$

$-$

$-$

$-$

$-$

$-$

$-$

$-$

$-$

$-$

$-$

$-$

$-$

$-$

$-$

101. Is a drop structure present? _ ( $Y$ or $N$, if $N$ type ctrl-n ds) 102. Distance: ___ feet 103. Drop: __ feet 104. Structure material: ___ (1- steel sheet pile; 2- wood pile; 3- concrete; 4- other) 105. Drop structure comments (eg. downstream scour depth):

$-$

$-$

$-$

-

$-$ 
106. Point/Side bar present? (Y or $N$. if $N$ type ctrl-n pb)Mid-bar distance:

Mid-bar width: -

Point bar extent: feet -

(US, UB, DS) to feet (US, UB, DS) positioned $\%$ LB to $\% \mathrm{RB}$ Material:

Point or side bar comments (Circle Point or Side; note additional bars, material variation, status, etc.):

S a cut-bank present? $\mathbf{N}$ (Y or if $N$ type ctrl-n cb) Where? $\underline{\mathbf{O}}$ (LB or RB) Mid-bank distance: PIE Cut bank extent: $\underline{\mathbf{R S}}$ feet ___ (US, UB, DS) to feet (US, UB, DS)

Bank damage: (1- eroded and/or creep; 2- slip failure; 3- block failure)

Cut bank comments (eg. additional cut banks, protection condition, etc.):

Is channel scour present? ( $Y$ or if $N$ type ctrl-n cs)

Mid-scour distance: $\underline{\mathbf{3}}$

Scour dimensions: Length 1 Width 432 Depth: 432

Positioned 1 $\%$ LB to $\mathbf{0}$ $\% \mathrm{RB}$ Scour comments (eg. additional scour areas, local scouring process, etc.): 435

0

2

-

Are there major confluences? 1 ( 1 or if $N$ type ctrl-n mc)

Confluence 1: Distance right Enters on ban ( $L B$ or RB)

How many? The

Confluence 2: Distance pro-

Enters on tec- $(L B$ or RB)

Type $\underline{\mathbf{k}}$ (1- perennial; 2- ephemeral)

Confluence comments (eg. confluence name):

Type tion (1- perennial; 2- ephemeral)

consists of concrete blocks extending from eight to eighty feet downstream. There are some trees leaning into the stream on the left bank. There is some stone fill along the left bank which is covered with sand and vegeta-

\section{F. Geomorphic Channel Assessment}

107. Stage of reach evolution tio

1- Constructed

2- Stable

3- Aggraded

4- Degraded

5- Laterally unstable

6- Vertically and laterally unstable 
108. Evolution comments (Channel evolution not considering bridge effects; See HEC-20, Figure 1 for geomorphic descriptors):

n. 


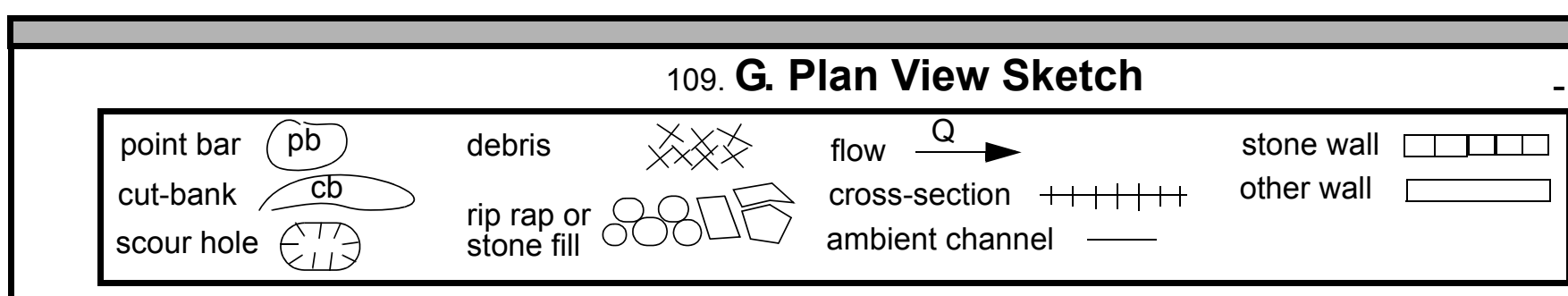


APPENDIX F:

SCOUR COMPUTATIONS 


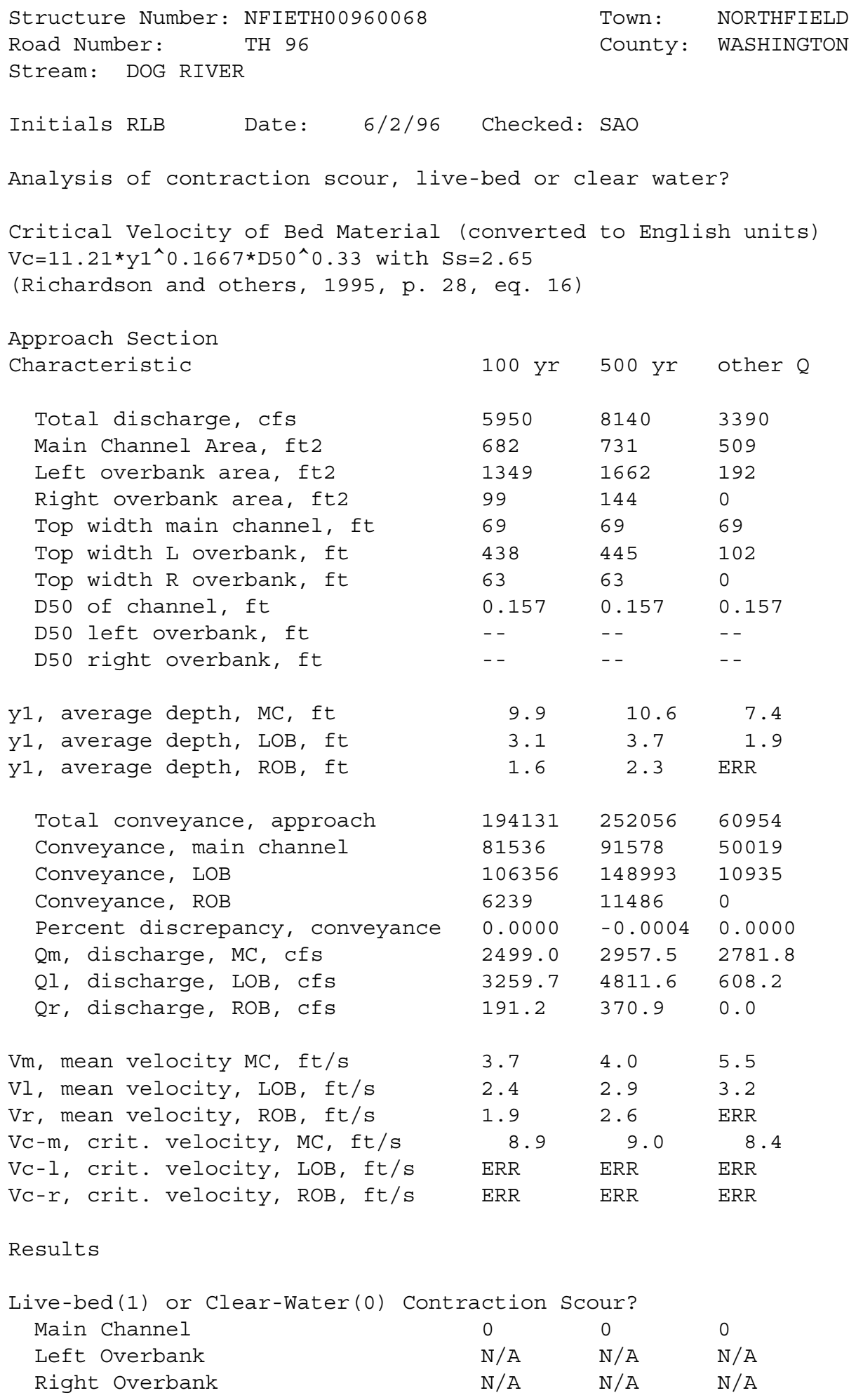


Clear Water Contraction Scour in MAIN CHANNEL

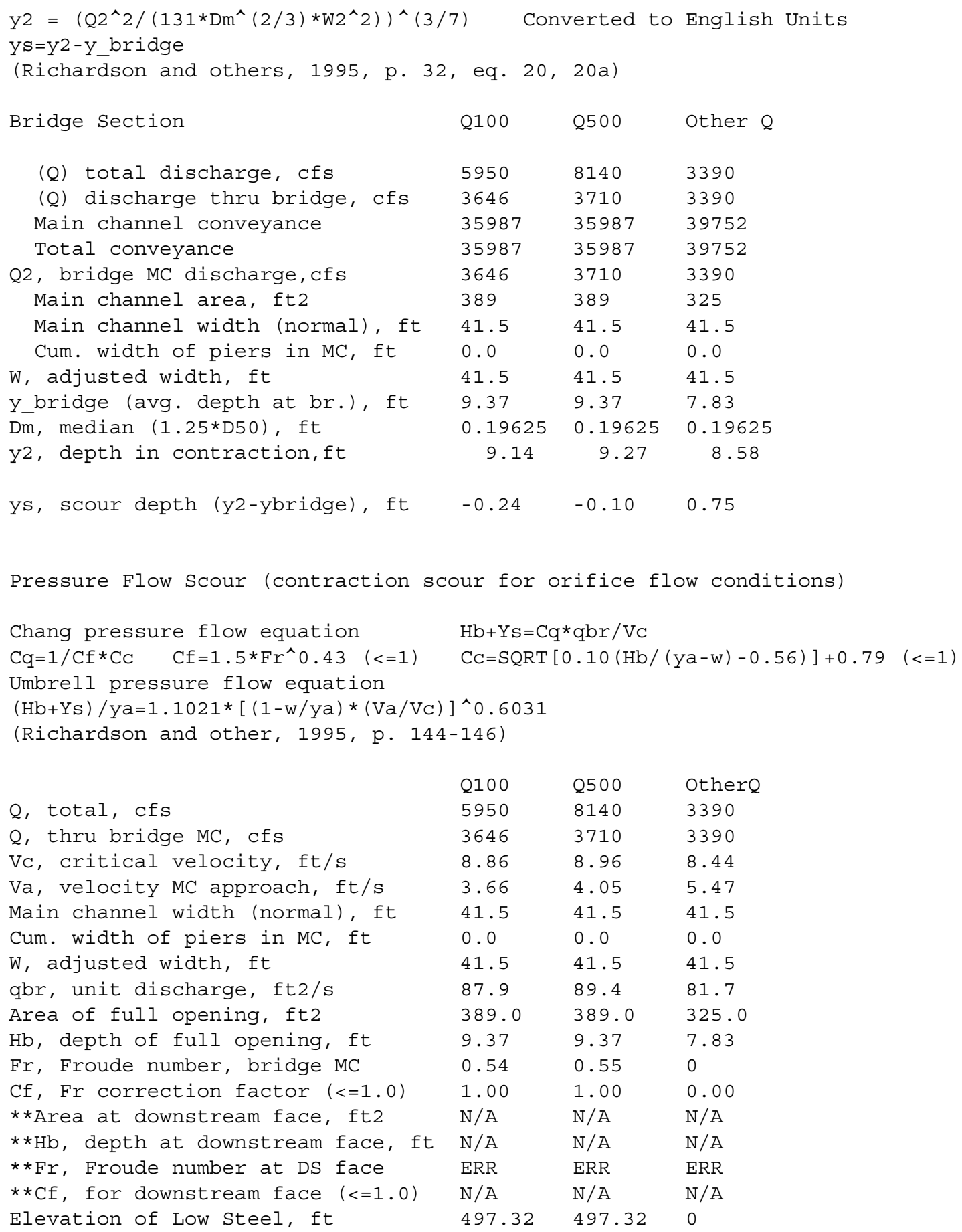




$\begin{array}{llll}\text { Elevation of Bed, ft } & 487.95 & 487.95 & -7.83 \\ \text { Elevation of Approach, ft } & 499.96 & 500.67 & 0 \\ \text { Friction loss, approach, ft } & 0.14 & 0.19 & 0 \\ \text { Elevation of WS immediately US, ft } & 499.82 & 500.48 & 0.00 \\ \text { ya, depth immediately US, ft } & 11.87 & 12.53 & 7.83 \\ \text { Mean elevation of deck, ft } & 499.78 & 499.78 & 0 \\ \text { w, depth of overflow, ft (>=0) } & 0.04 & 0.70 & 0.00 \\ \text { CC, vert contrac correction (<=1.0) } & 0.94 & 0.94 & 1.00 \\ \text { * CC, for downstream face (<=1.0) } & \text { ERR } & \text { ERR } & \text { ERR } \\ \text { YS, scour w/Chang equation, ft } & & & \\ \text { Ys, scour w/Umbrell equation, ft } & -1.15 & 1.21 & \mathrm{~N} / \mathrm{A} \\ \end{array}$

Armoring

\begin{tabular}{|c|c|c|c|}
\hline \multicolumn{4}{|l|}{$\begin{array}{l}\mathrm{DC}=\left[\left(1.94 * \mathrm{~V}^{\wedge} 2\right) /(5.75 * \log (12.27 * \mathrm{Y} / \mathrm{D} 90))\right. \\
\text { Depth to Armoring=3*(1/PC-1)} \\
\text { (Federal Highway Administration, 1993) }\end{array}$} \\
\hline Downstream bridge face property & $100-y r$ & $500-y r$ & Other \\
\hline Q, discharge thru bridge $M C$, cfs & 3646 & 3710 & 3390 \\
\hline Main channel area (DS), ft2 & 389 & 389 & 325 \\
\hline Main channel width (normal), ft & 41.5 & 41.5 & 41.5 \\
\hline Cum. width of piers, ft & 0.0 & 0.0 & 0.0 \\
\hline Adj. main channel width, ft & 41.5 & 41.5 & 41.5 \\
\hline D90, ft & 0.3823 & 0.3823 & 0.3823 \\
\hline D95, ft & 0.5563 & 0.5563 & 0.5563 \\
\hline Dc, critical grain size, ft & 0.2727 & 0.2823 & 0.3600 \\
\hline Pc, Decimal percent coarser than Dc & 0.191 & 0.176 & 0.113 \\
\hline Depth to arm & 3.46 & 3.97 & 8.48 \\
\hline
\end{tabular}

Abutment Scour

Froehlich's Abutment Scour

$\mathrm{Ys} / \mathrm{Y} 1=2.27 * \mathrm{~K} 1 * \mathrm{~K} 2 *\left(\mathrm{a}^{\prime} / \mathrm{Y} 1\right)^{\wedge} 0.43 * \mathrm{Fr} 1{ }^{\wedge} 0.61+1$

(Richardson and others, 1995, p. 48, eq. 28)

\begin{tabular}{|c|c|c|c|c|c|c|}
\hline \multirow[b]{2}{*}{ Characteristic } & \multicolumn{2}{|c|}{ Left Abutment } & \multicolumn{4}{|c|}{ Right Abutment } \\
\hline & $100 \mathrm{yr}$ & 500 yr Q & Other Q & $00 \mathrm{yr}$ & 00 yr & ther $Q$ \\
\hline (Qt), total discharge, cfs & 5950 & 8140 & 3390 & 5950 & 8140 & 3390 \\
\hline a', abut.length blocking flow, ft & 450 & 457.2 & 114 & 78.1 & 78.8 & 16.3 \\
\hline Ae, area of blocked flow ft 2 & 1026 & 1119.4 & 243.5 & 179.9 & 189.2 & 76.9 \\
\hline $\begin{array}{l}\text { Qe, discharge blocked abut., cfs } \\
\text { (If using Qtotal_overbank to obt }\end{array}$ & in $\mathrm{Ve}^{--}$ & ave $\mathrm{Qe}$ b & $\begin{array}{l}785.3 \\
\text { ank anc }\end{array}$ & ter $v$ & Id Fr & $\begin{array}{r}300.9 \\
\text { dally) }\end{array}$ \\
\hline $\mathrm{Ve},(\mathrm{Qe} / \mathrm{Ae}), \mathrm{ft} / \mathrm{s}^{-}$ & 2.43 & 2.91 & 3.23 & 2.47 & 2.89 & 3.91 \\
\hline ya, depth of $f / p$ flow, ft & 2.28 & 2.45 & 2.14 & 2.30 & 2.40 & 4.72 \\
\hline $\begin{array}{l}\text {--Coeff., K1, for abut. type (1.0, } \\
\text { K1 }\end{array}$ & $\begin{array}{l}\text { verti. ; } \\
0.82\end{array}$ & $\begin{array}{l}0.82, \text { ve: } \\
0.82\end{array}$ & $\begin{array}{r}\text { i. w/ } \\
0.82\end{array}$ & $\begin{array}{l}\text { gwall } \\
0.82\end{array}$ & $\begin{array}{l}55, \mathrm{sp} \\
0.82\end{array}$ & $\begin{aligned} \text { thru) } \\
0.82\end{aligned}$ \\
\hline
\end{tabular}




\begin{tabular}{|c|c|c|c|c|c|c|}
\hline theta & 90 & 90 & 90 & 90 & 90 & 90 \\
\hline $\mathrm{K} 2$ & 1.00 & 1.00 & 1.00 & 1.00 & 1.00 & 1.00 \\
\hline Fr, froude number $\mathrm{f} / \mathrm{p}$ flow & 0.240 & 0.261 & 0.389 & 0.262 & 0.274 & 0.317 \\
\hline ys, scour depth, ft & 19.53 & 21.48 & 14.49 & 10.92 & 11.50 & 12.15 \\
\hline \multicolumn{7}{|c|}{$\begin{array}{l}\text { HIRE equation }\left(a^{\prime} / \mathrm{Ya}>25\right) \\
\mathrm{Ys}=4 * \mathrm{Fr}^{\wedge} 0.33^{*} \mathrm{Y} 1 * \mathrm{~K} / 0.55 \\
\text { (Richardson and others, 1995, p. 49, eq. 29) }\end{array}$} \\
\hline a' (abut length blocked, ft) & 450 & 457.2 & 114 & 78.1 & 78.8 & 16.3 \\
\hline y1 (depth f/p flow, ft) & 2.28 & 2.45 & 2.14 & 2.30 & 2.40 & 4.72 \\
\hline$a^{\prime} / y 1$ & 197.37 & 186.74 & 53.37 & 33.91 & 32.82 & 3.46 \\
\hline Skew correction (p. 49, fig. 16) & 1.00 & 1.00 & 1.00 & 1.00 & 1.00 & 1.00 \\
\hline Froude no. f/p flow & 0.24 & 0.26 & 0.39 & 0.26 & 0.27 & 0.32 \\
\hline $\begin{array}{c}\text { Ys w/ corr. factor K1/0.55: } \\
\text { vertical }\end{array}$ & 10.35 & 11.43 & 11.37 & 10.77 & 11.39 & ERR \\
\hline vertical w/ $\mathrm{ww}^{\prime} \mathrm{s}$ & 8.49 & 9.37 & 9.33 & 8.83 & 9.34 & ERR \\
\hline spill-through & 5.69 & 6.29 & 6.26 & 5.92 & 6.26 & ERR \\
\hline
\end{tabular}

Abutment riprap sizing

Isbash Relationship

$\mathrm{D} 50=\mathrm{y} * \mathrm{~K} * \mathrm{Fr} \wedge 2 /(\mathrm{Ss}-1)$ and $\mathrm{D} 50=\mathrm{y} * \mathrm{~K} *\left(\mathrm{Fr} r^{\wedge} 2\right)^{\wedge} 0.14 /(\mathrm{Ss}-1)$

(Richardson and others, 1995, p112, eq. 81,82)

\begin{tabular}{|c|c|c|c|c|c|c|}
\hline Downstream bridge face property & Q100 & Q500 & Other $Q$ & Q100 & Q500 & Other $Q$ \\
\hline Fr, Froude Number & 0.54 & 0.55 & 0.66 & 0.54 & 0.55 & 0.66 \\
\hline y, depth of flow in bridge, ft & 9.37 & 9.37 & 7.83 & 9.37 & 9.37 & 7.83 \\
\hline Median Stone Diameter for riprap & : left & acment & & right & abutment & ft \\
\hline Fr< $<0.8 \quad$ (vertical abut.) & 1.69 & 1.75 & 2.11 & 1.69 & 1.75 & 2.11 \\
\hline Fr>0.8 (vertical abut.) & ERR & $\mathrm{ERR}$ & ERR & ERR & ERR & ERR \\
\hline
\end{tabular}


